\title{
Same Degree, Same Opportunities? Educational and Social Background Effects on Overeducation in Germany
}

\author{
Ana Santiago Vela
}

check for updates

Citation: Santiago Vela, Ana. 2021. Same Degree, Same Opportunities? Educational and Social Background Effects on Overeducation in Germany. Social Sciences 10: 315. https:// doi.org/10.3390/socsci10080315

Academic Editor:

Queralt Capsada-Munsech

Received: 18 June 2021

Accepted: 17 August 2021

Published: 20 August 2021

Publisher's Note: MDPI stays neutral with regard to jurisdictional claims in published maps and institutional affiliations.

Copyright: (C) 2021 by the author. Licensee MDPI, Basel, Switzerland. This article is an open access article distributed under the terms and conditions of the Creative Commons Attribution (CC BY) license (https:// creativecommons.org/licenses/by/ $4.0 /)$.
Section Qualifications, Occupational Integration, and Employment, Federal Institute for Vocational Education and Training (BIBB), 53175 Bonn, Germany; santiagovela@bibb.de

\begin{abstract}
Overeducation is indicative of a suboptimal education-job match and is related to several negative consequences for workers. Despite extensive research explaining the overeducation phenomenon, previous studies have not simultaneously analyzed educational background (i.e., educational degrees) and social background effects, or have failed to consider both the vertical and horizontal dimension that educational degrees entail (i.e., level and field). This article seeks to overcome these limitations by examining whether overeducation varies (1) across educational background (considering both level and field of educational degrees), (2) across social background, and (3) by social background among workers with the same degree. Based on the German BIBB/BAuA Employment Survey 2018, results suggest that highly educated workers are more likely to be overeducated for the jobs they hold, implying the supply of this workforce exceeds the available adequate jobs on the German labor market. The field of education determines the risk of overeducation as well, with some occupationally specific fields of education (IT, natural sciences, and health) making for lower overeducation risk for both vocational and academic education. The results also indicate social background directly influences education-job matches (controlling for level and field of education), i.e., a social gap in overeducation. This evidence suggests an effect of social background on job allocation processes, beyond the effect of education, so that the offspring of privileged classes (i.e., high salariat) use the same degrees on the labor market more profitably than the offspring of less privileged classes. Given the low attention paid to education-job matches in social stratification analyses, the present article makes a noteworthy contribution to the literature on social stratification and inequality. In addition, the present research will serve as a base for future studies on overeducation including both the vertical and horizontal dimension of educational degrees.
\end{abstract}

Keywords: overeducation; educational mismatch; social background; educational level; educational fields; skills requirements

\section{Introduction}

Investments in human capital require that workers efficiently use their acquired educational investments by holding adequate jobs (jobs matching the workers' education level). Overeducation implies that human capital formally acquired through educational degrees is not put to productive use for an adequate job position. Due to its implications for a wide range of education and labor policies, this phenomenon has drawn attention for decades from the economic and social science literature (e.g., Borgna et al. 2019; Freeman 1976; Hartog 2000; Levels et al. 2014; McGuinness 2006; Pollmann-Schult and Büchel 2004; Quintini 2011; Verhaest and Van der Velden 2013). Overeducation is associated with both negative monetary (e.g., Bauer 2002; Daly et al. 2000; Duncan and Hoffman 1981; Hartog 2000; Sloane et al. 1999) and non-monetary consequences like job satisfaction, motivation, and productivity (e.g., Allen and Van der Velden 2001; Fleming and Kler 2008; Green and Zhu 2010). In order to meet the need of understanding this problematic phenomenon of underutilized educational degrees, analyses of the driving forces of overeducation are necessary. In this sense, the risks of overeducation are unequally distributed across social 
groups. Parents of privileged classes might provide their offspring not only with more resources to gain desirable educational outcomes, but also with better opportunities to allocate their educational degrees into an adequate position at the labor market.

Analyzing the interrelatedness of overeducation and social background is especially of interest from a social stratification perspective. Social stratification analyses have traditionally relied on the concept of the origin-education-destination (OED) triangle to represent the intergenerational reproduction of inequality (Blau and Duncan 1967; Hout 1988). The triangle underlies three pivotal associations, i.e., between social origins and educational attainment (OE), between educational attainment and destination at the labor market (ED), and between social origins and labor market destination (OD). Compared to the former two associations, the study of social origin effects on labor market outcomes has received less attention. In this relationship, education plays an intermediary role between origin and destination. If education does not fully mediate the relationship between origin and destination, a direct effect of social origin remains over and above the indirect effect that origin exerts on destination via the influence on educational variables. A direct effect of social background means that privileged parents transmit class advantages to their offspring through means other than education and that equivalent degrees do not lead to equivalent jobs, thus contradicting the thesis of "education as the great equalizer" (e.g., Bernardi and Ballarino 2016).

Drawing on these considerations, the present article considers overeducation (i.e., holding a job that requires lower education than the attained education) as the destination dimension and investigates this for the German labor market. We investigated whether access to adequate jobs avoiding overeducation differs between (1) degrees, between (2) social backgrounds, and between (3) workers with similar degrees but originating from different social backgrounds. Question (1) may thus be considered as an investigation of the ED association, question (2) as an analysis of the OD association (controlling for level and field of education), whereas question (3) evaluates heterogeneous effects of education in the association OD. To investigate these questions, four variables are pivotal: social background, field and level of education (which compounds both educational degrees), and overeducation.

Previous work has not simultaneously considered social and educational background (i.e., educational degrees) to explain overeducation. Educational degrees entail two dimensions (i.e., level and field) that have been analyzed in distinct frameworks.

With respect to the relationship between level of education and overeducation, Rohrbach-Schmidt and Tiemann (2011) revealed for Germany that the expansion of educational levels has been associated with higher overeducation risks. Countries with strong vocational education systems have also been associated with lower overeducation rates (Di Stasio et al. 2016; Verhaest and Van der Velden 2013).

Regarding fields of education, overeducation analyses remain silent for the group of vocational educated workers. Previous overeducation studies have focused on more highly educated workers, and an assessment of differences across educational levels (vocational and academic) is lacking. For the case of academic education, evidence for Germany has revealed that overeducation risks differ across fields (Berlingieri and Erdsiek 2012; Berlingieri and Zierahn 2014; Ortiz and Kucel 2008; Rossen et al. 2019). Accordingly, research has highlighted the relevance of differentiating higher education by fields for a more comprehensive understanding of overeducation risks (Barone and Ortiz 2011; Capsada-Munsech 2015; Ortiz and Kucel 2008; Rossen et al. 2019). The emerging qualitative distinctions at the same level of education driven by educational expansion processes pushes the horizontal differentiation represented by fields (Reimer et al. 2008).

For the study of overeducation, the present article understands educational degrees based on both its verticality (level) and horizontality (field). By focusing not exclusively on the level of higher education but also considering the vocational level, this work sheds light on an area that has not been previously examined in the literature. This consideration is especially meaningful for the case of Germany, where the group of vocational education 
comprises a very important part (about 60 percent) of the total employed population (Statistisches Bundesamt 2020).

Moreover, only very few studies have focused on parental social background and overeducation. Studying a group of university graduates in Germany, Erdsiek (2016) found a social background effect on overeducation. Capsada-Munsech (2015), focusing on Italy, proposed a comprehensive analysis of the influence of education level and social background on the overeducation risks of university graduates.

One aim of the present article is to discover whether social background matters in job allocation processes, beyond the effect of education, so that the offspring of privileged classes may use the same degrees on the labor market more profitably than the offspring of less privileged classes. Therefore, given the low attention paid to overeducation in social stratification analyses, this question is new from a social stratification perspective. While other social stratification studies have typically found support for direct social background effects (controlling for education) on several labor market outcomes (Ballarino et al. 2016; Hansen 2001; Iannelli and Paterson 2007; Jacob et al. 2015; Torche 2011), extending the question of social inequalities to the outcome of overeducation in Germany is crucial with regard to competing arguments.

On one hand, some evidence suggests increasing social fluidity and decreasing inequality related to social origin in educational attainment over the last decades in Germany (Breen and Luijkx 2004; Breen et al. 2010; Müller and Pollak 2015). On the other hand, alternative evidence claims a persistent inequality in education by social background (Shavit and Blossfeld 2003). Thus, social reproduction theorists argue that social background is critical even in the context of educational expansion, given that the offspring of more privileged classes benefit more than those of less privileged ones (Bar Haim and Shavit 2013), leading to an effectively maintained inequality (Lucas 2001).

In addition to analyzing social inequalities in overeducation, we examine whether the social inequalities in overeducation (social gap in overeducation) differ across level and field of education. In so doing, we expand on previous work in other countries focusing on social background inequalities in higher education (Hansen and Mastekaasa 2006; Torche 2011) and suggesting that the effect of social background on labor market outcomes differs across educational levels (Bouchet-Valat et al. 2016; Breen and Jonsson 2007; Hout 1988). Moreover, we build on the previous study of Italian graduates by Capsada-Munsech (2015), which investigated the combined effect of social background with fields of education. Acknowledging previous evidence suggesting that fields in German higher education are affected by social selectivity (Reimer and Pollak 2010), we extrapolate the question of differing social background effects across fields to Germany.

The general merit of the present article is the integration of social and educational background into a combined framework in order to reveal patterns of overeducation. Previous studies have focused on either overeducation and social background or overeducation and fields of education, or have examined alternative labor market outcomes other than overeducation (e.g., Hansen 2001). To the best of our knowledge, this is the first analysis considering both social background and educational background (measuring both levels and fields) for the investigation of overeducation. Moreover, the analyses cover these novel questions for the concrete case of Germany. Given that the existing evidence has focused on the group of academic workers, this article provides first evidence for workers who are vocationally educated, a group that is of particular relevance in the German labor market.

\section{Theoretical Background and Hypotheses}

\subsection{Overeducation: A Conceptual Approach for a Relevant Phenomenon}

Overeducation is a type of vertical mismatch on the labor market. Vertical mismatches rely on comparisons between levels of job requirements and levels of job holders' endowments, where requirements and endowments may refer either to formal education or to skills. Overeducation, which appears if the attained education level of a worker is higher 
than the level required on the job, has traditionally represented the fundamental pillar of mismatch research (e.g., McGuinnes et al. 2018).

Analyses of educational mismatch are often based on the assumption, in an explicit or implicit way, that education level is a good proxy for skills of workers. However, for a transparent analysis of overeducation and in order to derive adequate implications, it is necessary to differentiate overeducation from skills-related mismatch. Skills-related mismatch is a different situation, as supported by recent research considering education and skills mismatch as different and low correlated phenomena (Allen et al. 2013; Allen and Van der Velden 2001; Flisi et al. 2017; Quintini 2011; Rohrbach-Schmidt and Tiemann 2016). ${ }^{1}$

From a theoretical perspective, different approaches have been used to analyze overeducation (e.g., Capsada-Munsech 2017; McGuinness 2006) like the human capital theory (Becker 1964), job competition and signaling theories (Spence 1973; Thurow 1975), and matching and career mobility theories (Sichermann 1991; Sichermann and Galor 1990). From the lens of classical human capital theory, educational mismatch can only be explained as an apparent phenomenon, i.e., reflecting workers' heterogeneity regarding skills and competencies within the same education level, or as a temporary phenomenon, i.e., reflecting career mobility strategies of workers. Nevertheless, it seems adequate to broaden the focus from a human capital perspective and consider both workers' characteristics as well as job characteristics (Rohrbach-Schmidt and Tiemann 2016).

With respect to the consequences of overeducation, numerous analyses have concluded that overeducated workers earn less than adequately matched workers with the same educational level and more than workers who do the same job but have less education (e.g., Bauer 2002; Daly et al. 2000; Duncan and Hoffman 1981; Hartog 2000; Sloane et al. 1999). Whereas some evidence on the German labor market linked negative wage effects of overeducation to lower skills of overeducated workers (Bauer 2002), other studies have found that wage penalties of overeducation stem from a poor matching rather than from heterogeneous skills or abilities between overeducated and well-matched workers (Kleibrink 2016).

Beside monetary consequences, the underutilization of the acquired educational degree is detrimental in other aspects. Job satisfaction, motivation, and productivity are negatively affected by overeducation (e.g., Allen and Van der Velden 2001; Fleming and Kler 2008; Green and Zhu 2010). Given the related negative consequences, a better understanding of the driving forces behind overeducation would be beneficial from a policy perspective.

The use of different overeducation measures leads to different results and implications (Verhaest and Omey 2010), and thus complicates comparability of empirical evidence. Overeducation can be measured via an objective or subjective approach (see CapsadaMunsech 2019 for an extensive discussion on overeducation measures). Measures using Job Analysis (JA) or Realized Matches (RM) indicators belong to the objective approach, and they differ in how to assess educational requirements. ${ }^{2}$ Subjective approaches, in contrast, are based on self-reported educational requirements for a job (i.e., workers' selfassessments, WA). Since there is no consensus on the operationalization and each of the measures have advantages and drawbacks, the use of multiple indicators should contribute to a comprehensive analysis of the overeducation phenomenon (Capsada-Munsech 2019).

In the present article, we interpret overeducation as an indicator of non-monetary return on education linked to outcomes that are detrimental to the workers (e.g., income and job satisfaction). Moreover, we assess the role of social background in explaining overeducation risks, considering different levels and fields of education. In so doing, the relevance from a perspective of social stratification and mobility is highlighted, in the sense that more privileged classes are assumed to benefit the most from educational attainment and make better use of credentials for desirable labor market positions. In other words, workers originating from less privileged social backgrounds are expected to have fewer opportunities for an adequate job position than workers originating from privileged families, even though they acquired similar degrees (similar educational attainment) and are thus comparable in terms of formal human capital. 


\subsection{Overeducation across Educational Levels}

Taking the definition of overeducation into account, it may be seen as tautological to discuss whether higher levels of education are more likely associated with overeducation. After acquiring higher educational levels, highly educated individuals may more often end up in jobs requiring lower educational levels compared to how often less educated individuals end up in jobs requiring lower education levels than they have achieved. In other words, whereas a university graduate would be considered overeducated in a job requiring upper-secondary education, an individual with upper-secondary education would be instead considered adequate for that job (educational match).

However, to grasp the interplay between overeducation and educational levels, it is necessary to consider that the occurrence of overeducation is determined both by supply and demand factors (i.e., educational level of individuals and jobs with adequate requirements, respectively). This juxtaposition of both factors is relevant for a better understanding of the phenomenon of overeducation and has already been considered in recent comparative overeducation analyses focusing on the subgroup of tertiary educated graduates (Green and Henseke 2021) or, more comprehensively, considering all educational levels (Capsada-Munsech 2017). In this vein and following empirical and theoretical arguments, we discuss below which level(s) of education may convey more risk of underutilization of the acquired educational degree.

Overeducation trends are usually analyzed in the context of educational expansion. In Germany, the expansion of educational levels has been associated with higher incidence of overeducation and credential inflation (Rohrbach-Schmidt and Tiemann 2011). However, an expanded supply of a more highly educated workforce does not necessarily imply higher incidence of overeducation if the demand for jobs requiring a more highly educated workforce increases accordingly (Croce and Ghignoni 2012). If, on the contrary, the increase in demand for highly educated workers is slower than the supply, the incidence of overeducation should increase (Davia et al. 2017). Moreover, recent evidence suggests that wage premiums for highly educated male workers increased during educational expansion processes in West Germany (Alda et al. 2020).

According to the supply-side-focused job competition model (Thurow 1975), allocation processes of education on the labor market are structured by the labor and job queue. The model implies that employers rank jobs in a hierarchical queue and that job seekers are ranked in the queue according to the available jobs. Moreover, the position of job seekers in the queue depends on the signals of skills and trainability they send, so that educational level is considered the strongest signal (Spence 1973). ${ }^{3}$ Consequently, as the position of individuals in the queue is determined by the educational level attained, highly educated individuals should send stronger signals to the employers and get better positions in the labor queue than individuals with lower educational attainment. Better jobs (with high educational requirements) are thus preferably assigned to individuals better positioned in the labor queue. Since a better position translates into better jobs, one may expect highly educated individuals to be less at risk of overeducation (getting inadequate jobs with low requirements) than individuals with lower education levels.

Derived from this queuing theory, there are arguments about the positional value of education. By acquiring higher educational levels, job seekers may ensure a better position in the labor queue, i.e., staying ahead of the queue. In this situation, education acquires a positional value, in the sense that it is the educational attainment relative to that of other job seekers (e.g., position in the queue) that matters for access to adequate jobs (Di Stasio et al. 2016). Following this reasoning, one could expect lower risks of overeducation for highly educated than for less educated workers.

Another implication of this theoretical argument, however, should be considered. Vocationally oriented countries with strong vocational education systems (defined as the relative size of the vocational sector in the secondary education system) have been associated with lower overeducation rates (Di Stasio et al. 2016; Verhaest and Van der Velden 2013). One could infer from this evidence that vocational education degrees should 
lead to better education-job matches than other higher (academic) degrees. Moreover, the function of education with a positional value is given in contexts where a competition for jobs exists, and that is the case especially in processes of educational expansion of tertiary education (Bol 2015; Di Stasio et al. 2016). More competitiveness due to increased supply of educational levels may lead to workers overeducating themselves (Ortiz and RodriguezMenés 2016), and thus to higher risks of overeducation for the highly educated workers.

Changing the focus from supply to demand arguments, the routine-biased technological change may contribute additional arguments. It is suggested that, due to technological change, routine jobs typically performed by medium-skilled workers are more prone to substitution processes than those typically performed by high-skilled (highly educated) workers, so that returns on education for the highly educated group should show an upward trend (Acemoglu and Autor 2011; Autor et al. 2003). This hypothesis, extensively discussed with regards to Germany in recent years (Antonczyk et al. 2018; Spitz-Oener 2006), may allow for extrapolation to the question of overeducation among different educational levels (understanding overeducation as a non-monetary return on education).

An additional point to consider is the social selectivity among educational levels, i.e., among vocational and academic education. One may interpret the well-known social selectivity in (the system of) higher education in Germany (Reimer and Pollak 2010; Schindler and Reimer 2011) as a mechanism leading to better job matches among workers with higher education degrees. However, it is necessary to consider that social selectivity is also present in the German system of vocational education and training and that there is even a direct influence of social background among individuals with vocational degrees as well (Beicht and Walden 2015).

Considering these contrary arguments, we pose the following competing and thereby mutually exclusive hypotheses:

Hypothesis 1a (H1a). The risk of overeducation will be higher among workers with vocational education than among academically educated workers.

Hypothesis $\mathbf{1 b} \mathbf{( H 1 b ) . ~ T h e ~ r i s k ~ o f ~ o v e r e d u c a t i o n ~ w i l l ~ b e ~ h i g h e r ~ a m o n g ~ a c a d e m i c a l l y ~ e d u c a t e d ~}$ workers than among workers with vocational education.

\subsection{Overeducation across Educational Fields}

Previous overeducation research considering educational fields focused on higher education, whereas differences across levels of education (vocational and academic) have not been analyzed so far. For the case of academic education, single-country and multiplecountry studies have confirmed cross-field differences in the overeducation risks of graduates in Germany (Berlingieri and Erdsiek 2012; Berlingieri and Zierahn 2014; Ortiz and Kucel 2008; Rossen et al. 2019). The empirical evidence supports the importance of higher education differentiation in the form of field of study for understanding overeducation risks (Barone and Ortiz 2011; Ortiz and Kucel 2008).

The role of fields of education may become more relevant as a consequence of the horizontal (qualitative) differentiation in higher education in the course of educational expansion. With increasing supply of higher education, higher degrees become less and less exclusive and selective. In order to circumvent the devaluation of higher degrees (e.g., decreasing signal power of higher education), privileged classes (which were previously dominant in this educational level) have strong incentives to promote alternative mechanisms of horizontal differentiation via fields of education. This argument is supported by evidence confirming that the higher the supply of highly educated individuals, the greater the differences in labor market outcomes of graduates from different fields (Reimer et al. 2008). Thus, fields of study may develop into a mechanism of qualitative social differentiation used by privileged classes to differentiate themselves and maintain privileges in increasingly competitive situations (Barone and Ortiz 2011; Capsada-Munsech 2015). This theoretical perspective on fields of education has been applied in studies outside the overeducation literature (e.g., Torche 2011; Triventi et al. 2017) and reveals the relevance of 
considering educational fields as a horizontal social differentiation mechanism (see Barone and Schindler 2014 for a theoretical approach).

Regarding how to differentiate educational fields, several theoretical approaches prove helpful in the context of overeducation. According to human capital arguments (Becker 1962), specific skills should be more rewarding than general skills. Scientific and technical fields of education may provide occupation-specific skills compared to general fields like humanities (Reimer et al. 2008). Following a signaling perspective (Spence 1973), certain fields may represent differing signaling effects and be considered more selective and strongly associated with ability and motivation. In addition, social closure mechanisms may also help to explain cross-field differences via restricting access to specific occupations, so that some positions on the labor market are more restricted than others (Bol and Weeden 2014; Weeden 2002). ${ }^{4}$ Distinguishing between general and specific/technical educational fields, Ortiz and Rodriguez-Menés (2016) showed that specific/technical education transmits a clearer signal of workers' skills to employers and may thereby be more resistant to the eventual devaluation effects in the course of educational expansion. ${ }^{5}$ We therefore derive the following hypothesis:

Hypothesis 2 (H2). The risk of overeducation will be lower in more occupationally specific fields of education (like health and IT) than in less specific, more general fields.

To characterize specific degrees, previous analyses frequently focused on a dual differentiation at the educational level, i.e., a separation of vocational and academic education. The underlying argument assumes that degrees at the vocational level are (considered as) specific and higher education (i.e., degrees at the academic level) general. However, recent studies have argued that this differentiation (academic vs. vocational) does not capture the heterogeneity of educational qualifications within the same educational level, suggesting a disaggregated differentiation of degrees within levels (Bol et al. 2019; Forster and Bol 2018). Following this critical point, we present analyses of educational fields separated by educational levels. In this way, we use appropriate evaluations of level-specific field effects, characterizing degrees by their vertical and horizontal dimension (level and field, respectively). ${ }^{6}$

\subsection{Social Background and Overeducation}

Early stratification research (e.g., Blau and Duncan 1967) has shown that social background can yield indirect effects on labor market outcomes (occupational prestige) via education, but it may also have a direct impact on labor market success (i.e., controlling for education). For the present analyses, the question is whether such a direct effect of social origin can be observed when it comes to overeducation, i.e., whether there is a social gap in overeducation.

Literature on this question is rather scarce and the literature that does exist is mainly focused on one educational level, that is the group of highly educated workers. The results of Erdsiek (2016) showed a social background effect on overeducation among German university graduates. This social background effect is partially mediated through ability, skills, study characteristics (like fields and institutional quality), and social capital, even though a part of the social gap in overeducation (40 percent) still remains unexplained by differences in observable mediators (Erdsiek 2016). Moreover, Capsada-Munsech (2015) pointed out that social background affects overeducation risks of university graduates in Italy. Additionally, other studies have shown that coming from a more privileged background is associated with several desirable labor market outcomes, over and above the effect of education (Ballarino et al. 2016; Hansen 2001; Torche 2011).

The literature on social origins referring to outcomes other than overeducation can be adapted and extrapolated to the question of a social gap in overeducation. Competing approaches may thus be used for the analysis of a direct effect of social background. On one hand, the modernization hypothesis predicts that economic development goes along with 
increasing meritocratic criteria and decreasing relevance of social origins for outcomes in the educational and labor system. This argument is reinforced by the trend of educational expansion over time, e.g., the supply growth of workers with higher education. In addition, one can infer from the human capital theory (Becker 1964) that workers with the same educational degrees (and same levels of human capital) achieve similar labor market returns and thereby parental background should not be relevant in explaining overeducation over and above the effect of educational attainment. Furthermore, similar to what has been experienced in other countries, inequality in educational attainment by social origin has declined over the 20th century in Germany (Breen et al. 2010). With this, an increase in the social fluidity can be observed (Breen and Luijkx 2004; Müller and Pollak 2015).

Alternative arguments from social reproduction theorists, on the other hand, have claimed a persistent inequality in education by social background (Shavit and Blossfeld 2003). Consequently, the status maintenance differentiation strategies of more privileged classes lead to an effectively maintained inequality (Lucas 2001). This differentiation will intensify in the course of educational expansion, so that individuals from privileged origins will use their resources to secure prestigious outcomes. Even acknowledging the relevance of education in explaining labor market outcomes, more inclusive access to higher education serves as an incentive for more privileged classes to develop alternative forms of differentiation in order to maintain their status. This social-specific differentiation (e.g., horizontal stratification), reflected in several channels like fields of education (Reimer and Pollak 2010) or type of higher education institution (Schindler and Reimer 2011), may explain labor market inequalities of individuals who share the same educational level but differ in their social background.

In processes of educational expansion, the increased supply of more highly educated workers may not necessarily be followed by a similar increase in the demand for jobs requiring higher education. If the supply of a highly skilled workforce exceeds the demand for suitable workplaces, overeducation may appear in response to that imbalance. In this scenario, the educational degrees acquired by workers would be underutilized in job positions that demand lower requirements. The queuing theory (Thurow 1975) speaks to this scenario by explaining that returns on education are influenced by the relative position of workers among all suppliers of work. Moreover, this job competition theory is central for a more comprehensive understanding of education and social background through the proposed concepts of matching of job and labor queues (Goldthorpe 2014, p. 278).

Therein, one can interpret education as a positional good, i.e., in relative rather than absolute terms. That is especially the case in the context of educational expansion, when education returns mainly depend on the relative position of workers on the job market. Then, education becomes increasingly positional (Bol 2015; Di Stasio et al. 2016). This approach of considering education as a positional good is compatible with findings of decreasing social inequality in educational attainment (Triventi et al. 2016). Moreover, more competitiveness due to increased supply of educational levels may lead to workers overeducating themselves (Ortiz and Rodriguez-Menés 2016). If an upgrade of the job structure does not take place after expansion of educational upgrading, recent cohorts of graduates will be faced with educational inflation (Triventi et al. 2016). This situation of increased competitiveness can result in difficulties in finding adequate jobs and avoiding overeducation.

In this paradigm, alternative sources of social differentiation at the horizontal level reinforce social inequalities. As pointed out by Goldthorpe (2014) and following the job competition theory, individuals' relative level of education becomes essential in a context of expanding educational levels as a defensive measure in order to be able to preserve high positions within the labor queue. Since this pressure is not necessarily demand-driven, overeducation is highly likely to occur, possibly resulting again "in more advantaged families taking the lead in processes of educational re-stratification, in which an expanding level of education becomes internally differentiated in terms of quality" (Goldthorpe 2014, p. 279). Offspring of more privileged classes might still make better use of their acquired 
educational degrees if they had access to other valuable resources. In general, it seems plausible that parental class and associated resources increase their offsprings' chance of finding a suitable job.

Social and cultural capital (Bourdieu 1984) act as instruments of higher social classes to maintain their privileges and may translate into more and higher skills of the offspring. This should allow privileged classes to distinguish themselves from other, less privileged classes with the same acquired educational levels even in the scenario of an increased social fluidity.

Possibilities of using professional networks (Granovetter 1983) may serve as an additional instrument to find a suitable job once the educational degree has been acquired. Previous research has pointed to a nuanced association between the use of strong and weak networks and positions on the German labor market (Weiss and Klein 2011). Additionally, evidence points to negative effects of informal networks (Kracke and Klug 2021) or to no effect of ethnic networks (Schuss 2020) on overeducation risks of migrant workers in Germany. The use of networks may thereby reflect a negative selection of workers, who make use of networks due to lacking alternatives for finding fitting jobs. Beyond the question of whether social networks have been used to find an adequate job (or not), having access to social networks should be considered in general as a resource that can be accessed if necessary. It is reasonable to argue that the unequal availability of this resource by social background may help as a mechanism to explain better opportunities to acquire adequate jobs among higher classes.

A social gap in overeducation (controlling for level and field of education) should appear. We therefore formulated the following hypothesis:

Hypothesis 3 (H3). Workers with a socially advantageous background will have lower overeducation risks than workers with less socially advantageous background (controlling for education).

Neglected so far in the literature is a differentiation of the social gap in overeducation by educational levels, such that no evidence exists on whether social background is related to overeducation risks for workers with vocational education to the same extent as for more highly educated workers. To answer this question, competing theories may be considered.

On one hand, following a differential social selection argument (Mare 1981), no effects of social background at higher educational levels should be expected. This argument, originally developed to explain stratification in education and commonly applied to analyses of the education system (e.g., Triventi 2013), can be extrapolated to labor market outcomes like overeducation.

On the other hand, the strong social selection in educational systems (Shavit and Blossfeld 2003) lead to the assumption that the higher the educational level, the higher the inequality in educational attainment by social class, i.e., the lower the odds of attaining higher educational degrees for less privileged classes. This social selectivity in education implies that workers originating from the less privileged class who do attain high educational levels should be characterized by excellent abilities, motivation, and effort put into career advancement (Hansen 2001). According to this reasoning, the higher efforts and career focus of highly educated workers originating from less privileged classes may compensate for their reduced resources and class-related disadvantages.

The same theoretical argument of the above-mentioned social selection can be reversed to support a contrary expectation, i.e., that the higher the educational levels, the higher the efforts and resources of those originating from privileged class. Juxtaposing contrasting views on class-specific ability and aspirations, one can thus argue that, instead of the less privileged classes showing more motivation, effort, and abilities, it is the more privileged classes that put more effort into pursuing adequate careers.

For some countries other than Germany, empirical evidence suggests that the effect of social background on labor market outcomes is weaker in the higher than in the lower educational levels (Breen and Jonsson 2007; Hout 1988). For instance, Bouchet-Valat et al. (2016) showed that there is a direct effect of social background in France, and that this social 
origin effect on job socioeconomic value is weaker among the more highly educated. One can infer from this finding that a more advantaged social background may compensate, to some extent, for less remarkable educational assets (Bouchet-Valat et al. 2016).

For the German case, empirical evidence suggests that social background still matters for the labor market outcomes of highly educated individuals (Jacob et al. 2015). Additional evidence indicates that the direct effect of social background on labor market position is stronger at lower educational levels than among highly educated individuals (Müller and Pollak 2015).

Theoretical arguments explaining why social background is also inequality-enhancing among advanced-degree holders are found in studies focusing on academic education. Investigating Norwegian graduates, Hansen and Mastekaasa (2006) used the concepts of the cultural capital (Bourdieu 1984) to analyze the positive association between class origin and academic performance. In the work of Torche (2011) for schooling levels in the United States, college degree was observed to serve as an equalizer for economic success. However, the author also argued that the expansion of advanced degrees goes along with a differentiation at the graduate level, so that an inequality-enhancing horizontal stratification becomes more relevant (channeled through fields of education and selective institutions) (Torche 2011). In a European analysis of the stratification in higher education, Triventi (2013) found evidence for an influence of social background on education, confirming "lingering effects" (i.e., an enduring social background effect at higher educational levels) also for Germany.

Overall, existing evidence is inconclusive regarding which one of the plausible mechanisms prevails. Following these lines of reasoning, we formulate the following competing, mutually exclusive hypotheses:

Hypothesis 4a (H4a). Inequality in overeducation risk by social background (social gap in overeducation) will be lower among academically educated workers than among workers with vocational education.

Hypothesis $\mathbf{4 b} \mathbf{b} \mathbf{H} \mathbf{4 b})$. Inequality in overeducation risk by social background (social gap in overeducation) will be lower among workers with vocational education than among academically educated workers.

Similar to level of education, differences in the social gap in overeducation by fields may appear. Occupation-specific fields should more likely lead to a homogeneous assessment of skills and abilities relevant for the occupation than less specific, more general fields of education. More occupationally specific fields of education seem to represent entry requirements for the corresponding occupations that are generally acknowledged by employers (Rossen et al. 2019). Employers may thereby more easily make assumptions about skills relevant for the job, without relying on additional information on personal and non-cognitive characteristics (Capsada-Munsech 2015). Individuals within the same occupation-specific field of education (same degree) should signalize very similar abilities and skills, and no differentiation or variability depending on family-related resources should be expected. That would imply that occupation-specific fields are more resistant to the inequality effect of social background.

In that case, where requirements are homogeneous and transparently assessed, other resources stemming, for example, from cultural capital or greater cognitive abilities should play a minor role. If, on the contrary, degrees in general fields imply a high variability in occupational abilities and are associated with a wider range of occupational possibilities, the advantage of additional resources should make a difference. Thus, social background should play a more important role in general fields characterized by higher heterogeneity in occupational skills than for occupation-specific, homogeneous fields.

For the sake of clarity, one can contemplate the requirements assigned to an academic degree in informatics or health. Degrees in these fields are associated with high labor market returns and adequate jobs and are more likely to be attained by individuals originating 
from privileged classes. However, individuals originating from less privileged classes who attain a degree in informatics should also be equally capable of using the specific skills acquired through education for performance at job. In other words, in less specific fields the social background matters more, so that workers with parents from higher classes are expected to show lower risks of overeducation (Capsada-Munsech 2015). Thus, we derive the following hypothesis:

Hypothesis 5 (H5). Inequality in overeducation risk by social background (social gap in overeducation) will be lower in specific than in general educational fields.

\subsection{Overview of Constructs and Hypotheses}

Figure 1 presents an overview of the hypotheses presented in this article. $\mathrm{H} 1 \mathrm{a} / \mathrm{b}$ and $\mathrm{H} 2$ represent the association between educational degree (defined in its two aspects: level and field) and the outcome of mismatched job (overeducation). H3 explores whether a social gap in overeducation when controlling for education exists, i.e., whether there is a direct effect of social background on overeducation risks or if, on the contrary, the effect is mediated through education (level and field). $\mathrm{H} 4 \mathrm{a} / \mathrm{b}$ and $\mathrm{H} 5$ address heterogeneity in the effect of social background by educational degree, i.e., if social background matters for all levels and fields of education equally or if, on the contrary, there are differences by educational degree.

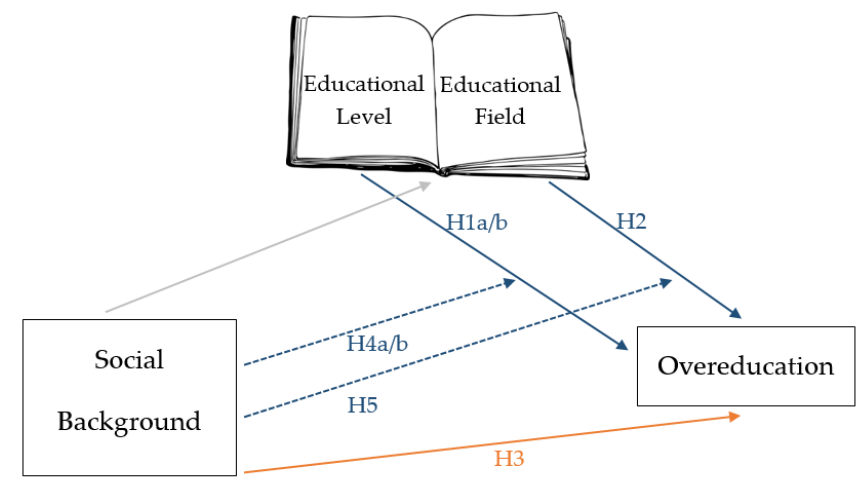

Figure 1. Overview of construct and hypotheses. Continuous blue and orange arrows present hypotheses for direct relationships and dashed blue arrows present hypotheses for interaction terms. The grey arrow is shown for the sake of completeness (relationship between social background and education) and it is not part of the analyses.

\section{Data and Methods}

The analyses use data from the BIBB/BAuA Employment Survey 2018 (Hall et al. 2020), a data set of more than 20,000 persons in active employment in Germany with a minimum of 10 working hours per week (excluding apprentices), and collected via computer-assisted telephone interviewing. The BIBB/BAuA Employment Survey 2018 is a dual-frame survey conducted with two comparable sampling frames as a combined landline and mobile sample (30 percent of interviews carried out on mobile telephony). Both sampling frames were merged ex post based on a design weighting to form a representative image of the basic population (Rohrbach-Schmidt and Hall 2020) ${ }^{7}$.

The data set includes rich information on educational and employment history of labor market participants as well as requirements and other workplace characteristics. Analyses are restricted to workers with an educational degree and aged 20 to 65 years old.

\subsection{Dependent Variable: Overeducation}

The measurement of overeducation is based on a subjective approach using workers' self-assessments. We compare workers' assessments of the level of education that is required to perform their job with the workers' actual educational level. For the assessment 
of the required educational level, workers were asked, "What type of training is usually required for performing your current job? A completed vocational training, a university of applied sciences degree or university degree, an advanced training degree, e.g., as a master craftsman or technician, or is no vocational training degree required?" If the educational level acquired by workers is higher than the education level they reported to be required at their workplace, they were classified as overeducated. ${ }^{8}$

Since there is no consensus on the measurement of overeducation, there are several viable approaches (Capsada-Munsech 2019). The main critique of subjective approaches for the measurement of overeducation is based on the possible measurement error due to social desirability, especially if workers overstate their job requirements (Leuven and Oosterbeek 2011; Verhaest and Omey 2010). However, compared to alternative objective approaches based on job experts' analysis or on statistical distributions of educational levels within occupations, workers' self-assessments have the advantage of considering heterogeneity at the workplace level (Hartog 2000; McGuinness 2006). This implies a finer grained evaluation of overeducation at the workplace, i.e., approximating the requirements needed to perform their specific jobs.

By using workers self-assessments, one implicitly refers to a match between workplaces and worker, rather than a match between occupations (aggregated workplaces) and workers. In addition, the subjective approach utilized in the present article is an indirect assessment of the overeducation status, since workers assessed the educational level requirement and did not directly evaluate their education-job match itself. It is reasonable to argue that accounting for this wording effect through indirect self-assessments is a good strategy to produce a robust measure for overeducation (Büchel 1998). Another strength of this overeducation indicator stems from the question measuring the required educational level. This question refers to the educational level "to perform/to do the job" and is less sensitive to credential inflation than other alternatives referring to the needed level "to get the job"(Hartog 2000).

Even though different measurement approaches might lead to different results, the use of various overeducation measures allows an overview of complementary results and may help to improve the understanding of this phenomenon (Capsada-Munsech 2019). We thereby re-ran all the analyses using an alternative measure for overeducation via an objective approach (JA) in order to enrich the scope of our results. ${ }^{9}$

We compared the actual educational level of employees with the formal requirement level of their job as defined in the German classification of occupations (Klassifikation der Berufe [KldB] 2010). ${ }^{10}$ If the educational level of employees was higher than the formal requirement level of their job, employees were considered overeducated. Compared to the subjective approach, the merits of the objective approach based on job analysis depend "on the level of aggregation, the time lag in the observation and the care and precision of the measurement procedure" (Hartog 2000, p. 133). The German classification of occupations from the year 2010, which distinguishes approximately 1286 different occupational types, should offer a reasonably good level of aggregation for job analysis measures of overeducation.

\subsection{Explanatory Variables}

Educational level is a dichotomized variable measuring the highest level of education of workers, which can be either an academic or a vocational degree. ${ }^{11}$

Fields of education are classified following the occupational segments based on the German classification of occupations 2010 (KldB 2010). The occupational segments are a preferable categorization compared to alternatives based on occupational areas, since the former categorization takes into account the occupational segmentation of the German labor market (Matthes et al. 2015). From the total 14 homogeneous segments proposed in the classification, we collapsed three of the categories (this aggregation proves necessary in order to have enough observations for posterior subgroup analyses) and distinguished 12 different segments, which represent the different fields of education, namely: (1) medical 
and non-medical health care; (2) agriculture, forestry, and horticulture; (3) manufacturing; (4) technology production; (5) building and interior construction; (6) gastronomy, food industry, and tourism; (7) social and cultural work; (8) commerce and trade; (9) business management and organization; (10) business related services; (11) IT-sector and natural sciences; and (12) security, traffic, logistics, and cleaning services.

Social background (i.e., social origin) is conceptualized based on parents' social class position. The indicator for social background measures parental social class in accordance with the Erikson-Goldthorpe-Portocarero (EGP) class schema (Erikson and Goldthorpe 1992; Erikson et al. 1979). ${ }^{12}$ For the sake of parsimony, the variable is dichotomized and takes the value 1 if fathers (or mothers, in case the information on fathers' occupation is missing) belong to the EGP class I (high salariat) and 0 otherwise (EGP class II, III $a+b$, $\mathrm{IVa}+\mathrm{b}+\mathrm{c}, \mathrm{V}, \mathrm{VI}, \mathrm{VII} a+b) .{ }^{13}$

\subsection{Control Variables and Analytical Strategy}

The analyses included several control variables; namely, gender, migration background, marital status, part-time work (less than $20 \mathrm{~h}$ per week), experience with the employer/firm (in years), region (Bundesland) of residence, residence relocation after finishing educational degree (whether place of highest acquired degree differs from place of residence), age (age groups), children living in the household, career aspiration (a dummy for workers who strongly pursue the goal of a career), and horizontal mismatch (through a variable capturing partial or total changes between acquired education/training occupation and current occupation).

Since the seminal theory of differential overqualification (Frank 1978), analyses have always proven that women are, despite decreasing trends (Henseke 2019), still at higher overeducation risk than men (e.g., Boll and Leppin 2016; Büchel and Battu 2003), and that this effect is also related to marital status, to regional labor markets, and to relocations (Büchel and Van Ham 2003; Croce and Ghignoni 2015). Migration background also affects overeducation risks (Kracke 2016; Nieto et al. 2015) as well as younger workers due to educational expansion processes, and workers with scarce employer experience are expected to be at higher risks of overeducation, especially if job-specific requirements are not met (Frei and Sousa-Poza 2012). Since social differences in career orientation are expected and they affect the likelihood of accepting an inadequate job, the analyses control for career aspiration of workers (Erdsiek 2016).

Controlling for horizontal changes of the attained education is essential to obtain fields' effects net of occupational changes. Since occupations may be more or less similar, a differentiation between total (less similar) and partial (more similar) occupational changes is helpful in capturing possible skills that are transferable after having changed the training occupation (Hall 2011).

Table 1 presents descriptive statistics of all variables used for the analyses, for the total sample, and for the subsample of overeducated and non-overeducated workers.

Logistic regression models were applied for the analysis of the dependent dummy variable. To test $\mathrm{H} 1 \mathrm{a} / \mathrm{b}, \mathrm{H} 2$, and $\mathrm{H} 3$ and in order to interpret and compare the regression coefficients, we computed average marginal effects (AME) (Mood 2010). Those AME are interpreted as the effect of the independent variable of interest on overeducation prediction. $\mathrm{H} 4 \mathrm{a} / \mathrm{b}$ and $\mathrm{H} 5$ entail interaction effects between social background and educational level and field, respectively. Given the complexity and difficulties of interpreting interaction effects in logistic regressions, we followed recommendations by Mize (2019) for non-linear interaction effects and considered predicted probabilities of overeducation to test $\mathrm{H} 4 \mathrm{a} / \mathrm{b}$ and $\mathrm{H} 5$. 
Table 1. Description of variables for all workers, as well as for overeducated and non-overeducated workers $(N=15,605)$. Unweighted proportions. Data: BIBB/BAuA Employment Survey 2018, authors' own calculations.

\begin{tabular}{|c|c|c|c|c|c|c|c|c|c|}
\hline & \multicolumn{3}{|c|}{$\begin{array}{c}\text { Total Sample } \\
\text { Prop. (\%) }\end{array}$} & \multicolumn{3}{|c|}{$\begin{array}{l}\text { Overeducated } \\
\text { Prop. }(\%)\end{array}$} & \multicolumn{3}{|c|}{$\begin{array}{c}\text { Non-Overeducated } \\
\text { Prop. (\%) }\end{array}$} \\
\hline Overeducation (vs. no) & \multicolumn{3}{|c|}{21.1} & \multirow{2}{*}{\multicolumn{3}{|c|}{19.7}} & \\
\hline EGP I, high salariat (vs. other EGP) & \multicolumn{3}{|c|}{21.5} & & & & \multirow{2}{*}{\multicolumn{3}{|c|}{$\begin{array}{l}22.0 \\
40.2\end{array}$}} \\
\hline Academic education (vs. vocational) & \multicolumn{3}{|c|}{40.2} & \multicolumn{3}{|c|}{40.9} & & & \\
\hline \multirow{2}{*}{\multicolumn{6}{|c|}{ Educational field }} & & \multicolumn{3}{|c|}{40.2} \\
\hline Agriculture, forestry, and horticulture & \multicolumn{3}{|c|}{2.7} & \multicolumn{3}{|c|}{3.8} & & \multirow{2}{*}{\multicolumn{2}{|c|}{2.4}} \\
\hline Manufacturing & & 6.4 & & & 8.2 & & & & \\
\hline Technology production & & 13.1 & & & 12.3 & & & 13.4 & \\
\hline Building and interior construction & & 5.4 & & & 5.5 & & & 5.4 & \\
\hline Gastronomy, food industry, and tourism & & 3.6 & & & 5.1 & & & 3.1 & \\
\hline Medical and non-medical health care & & 12.4 & & & 9.8 & & & 13.1 & \\
\hline Social and cultural work & & 17.5 & & & 14.5 & & & 18.4 & \\
\hline Commerce and trade & & 5.4 & & & 6.8 & & & 4.9 & \\
\hline Business management and organization & & 11.2 & & & 13.5 & & & 10.5 & \\
\hline Business related services & & 11.6 & & & 10.4 & & & 12.0 & \\
\hline IT-sector and natural sciences & & 7.2 & & & 6.2 & & & 7.5 & \\
\hline Security, traffic, logistics, cleaning & & 3.6 & & & 4.2 & & & 3.5 & \\
\hline Women (vs. men) & & 50.2 & & & 51.8 & & & 49.7 & \\
\hline Migration background (vs. no) & & 9.9 & & & 12.1 & & & 9.2 & \\
\hline Marital Status & & & & & & & & & \\
\hline Unmarried & & 28.2 & & & 30.7 & & & 27.6 & \\
\hline Married & & 59.3 & & & 56.3 & & & 60.2 & \\
\hline Divorced & & 12.5 & & & 13.1 & & & 12.2 & \\
\hline Children living in household (vs. no) & & 33.0 & & & 29.5 & & & 34.0 & \\
\hline Age group (years) & & & & & & & & & \\
\hline $15-34$ & & 16.2 & & & 14.7 & & & 16.6 & \\
\hline $35-44$ & & 20.6 & & & 18.6 & & & 21.1 & \\
\hline $45-54$ & & 33.5 & & & 34.9 & & & 33.2 & \\
\hline $55-64$ & & 28.9 & & & 31.0 & & & 28.4 & \\
\hline 65 & & 0.7 & & & 0.8 & & & 0.7 & \\
\hline Region (Bundesland) & & & & & & & & & \\
\hline Schleswig-Holstein & & 3.4 & & & 3.0 & & & 3.6 & \\
\hline Hamburg & & 2.8 & & & 3.2 & & & 2.7 & \\
\hline Lower Saxony & & 9.3 & & & 8.8 & & & 9.5 & \\
\hline Bremen & & 0.8 & & & 1.0 & & & 0.8 & \\
\hline North Rhine-Westphalia & & 18.0 & & & 17.6 & & & 18.0 & \\
\hline Hesse & & 7.0 & & & 7.4 & & & 6.9 & \\
\hline Rhineland-Palatinate & & 4.2 & & & 4.3 & & & 4.2 & \\
\hline Baden-Württemberg & & 12.0 & & & 10.8 & & & 12.3 & \\
\hline Bavaria & & 20.2 & & & 19.8 & & & 20.3 & \\
\hline Saarland & & 1.0 & & & 1.0 & & & 1.1 & \\
\hline Berlin & & 6.0 & & & 6.3 & & & 5.9 & \\
\hline Brandenburg & & 3.0 & & & 3.2 & & & 3.0 & \\
\hline Mecklenburg-Vorpommern & & 1.8 & & & 1.9 & & & 1.8 & \\
\hline Saxony 0 & & 5.1 & & & 5.9 & & & 4.9 & \\
\hline Saxony-Anhalt & & 2.6 & & & 3.0 & & & 2.5 & \\
\hline Thuringia & & 2.6 & & & 2.9 & & & 2.6 & \\
\hline Residence relocation (vs. no) & & 29.2 & & & 31.9 & & & 28.4 & \\
\hline Part-time work $<20$ hrs. (vs. full time) & & 5.3 & & & 10.0 & & & 4.0 & \\
\hline Strong career orientation (vs. no) & & 32.8 & & & 30.1 & & & 33.7 & \\
\hline Change of field/occupation & & & & & & & & & \\
\hline No occ. change & & 30.9 & & & 18.1 & & & 34.7 & \\
\hline Partial occ. change & & 41.5 & & & 31.2 & & & 44.4 & \\
\hline Total occ. change & & 27.5 & & & 50.7 & & & 20.9 & \\
\hline & & al sam & & & Dvereducat & & & veredu & \\
\hline & Mean & $\begin{array}{l}\text { Std. } \\
\text { Dev. }\end{array}$ & $\begin{array}{l}\text { Min- } \\
\text { Max }\end{array}$ & Mean & $\begin{array}{l}\text { Std. } \\
\text { Dev. }\end{array}$ & $\begin{array}{l}\text { Min- } \\
\operatorname{Max}\end{array}$ & Mean & $\begin{array}{l}\text { Std. } \\
\text { Dev. }\end{array}$ & $\begin{array}{l}\text { Min- } \\
\text { Max }\end{array}$ \\
\hline Experience current employer/firm (years) & 13.9 & 11.2 & $0-50$ & 12.0 & 10.5 & $0-50$ & 14.4 & 11.4 & $0-50$ \\
\hline
\end{tabular}




\section{Results \\ 4.1. Educational Levels and Fields}

Table 2 displays several logit regression models to analyze the relationship between overeducation risks and the level and field of educational degrees. M0, which included the educational level and control variables, suggested that more highly educated workers were more likely to be overeducated for their job than workers with vocational education. This different overeducation risk may have appeared due to differences in the distribution of fields of education. However, after controlling for fields of education in M1, the significant difference in overeducation risk remained and became even larger. Thus, more highly educated workers had, on average, an eight-percentage point higher probability of overeducation risk than vocationally educated workers, supporting H1b instead of H1a. In the vocationally oriented German labor market, vocational degrees perform better than academic degrees in preventing overeducation, net of specific fields effects, suggesting that the average demand for high-skills jobs cannot sufficiently accommodate the average supply of highly skilled workers.

Table 2. Logit regression models of overeducation (subjective indicator) on educational level and educational fields (AME) ${ }^{1}$.

\begin{tabular}{|c|c|c|c|c|c|}
\hline & Mo & M1 & M2 & M2a & M2b \\
\hline & Ed. Level & $\begin{array}{l}\text { Ed. Level } \\
\text { + Fields }\end{array}$ & Fields & $\begin{array}{l}\text { Fields, Only } \\
\text { Vocational }\end{array}$ & $\begin{array}{l}\text { Fields, Only } \\
\text { Academic }\end{array}$ \\
\hline Academic education & $\begin{array}{l}0.06^{* * *} \\
(0.010)\end{array}$ & $\begin{array}{l}0.08^{* * *} \\
(0.012)\end{array}$ & & & \\
\hline \multicolumn{6}{|l|}{$\begin{array}{l}\text { Ref.: medical and non-medical } \\
\text { health care }\end{array}$} \\
\hline Agriculture, forestry and & & $0.07^{*}$ & $0.07 *$ & 0.05 & $0.14^{* *}$ \\
\hline horticulture & & $(0.028)$ & $(0.028)$ & $(0.032)$ & $(0.052)$ \\
\hline \multirow{2}{*}{ Manufacturing } & & $0.05 *$ & 0.04 & 0.02 & $0.22^{* * *}$ \\
\hline & & $(0.020)$ & $(0.020)$ & $(0.022)$ & $(0.058)$ \\
\hline \multirow[t]{2}{*}{ Technology production } & & 0.04 & 0.03 & 0.02 & 0.06 \\
\hline & & $(0.018)$ & $(0.018)$ & $(0.022)$ & $(0.034)$ \\
\hline Building and interior & & $0.07^{* *}$ & $0.06^{* *}$ & 0.05 & $0.10 *$ \\
\hline construction & & $(0.024)$ & $(0.024)$ & $(0.028)$ & $(0.048)$ \\
\hline Gastronomy, food & & $0.11^{* * *}$ & $0.09^{* * *}$ & $0.09^{* * *}$ & 0.17 * \\
\hline industry and tourism & & $(0.026)$ & $(0.025)$ & $(0.027)$ & $(0.084)$ \\
\hline \multirow[t]{2}{*}{ Social and cultural work } & & 0.01 & $0.04 *$ & 0.04 & 0.02 \\
\hline & & $(0.017)$ & $(0.016)$ & $(0.026)$ & $(0.028)$ \\
\hline \multirow[t]{2}{*}{ Commerce and trade } & & $0.07^{* *}$ & $0.06^{* *}$ & $0.06 * *$ & 0.19 \\
\hline & & $(0.023)$ & $(0.022)$ & $(0.023)$ & $(0.095)$ \\
\hline Business management & & $0.06^{* *}$ & $0.06^{* * *}$ & 0.02 & $0.16^{* * *}$ \\
\hline and organization & & $(0.018)$ & $(0.018)$ & $(0.020)$ & $(0.035)$ \\
\hline \multirow[t]{2}{*}{ Business related services } & & 0.03 & $0.04 *$ & 0.02 & 0.06 \\
\hline & & $(0.018)$ & $(0.018)$ & $(0.021)$ & $(0.034)$ \\
\hline IT-sector and natural & & -0.01 & 0.02 & -0.05 & 0.03 \\
\hline sciences & & $(0.019)$ & $(0.020)$ & $(0.026)$ & $(0.032)$ \\
\hline Security, traffic, logistics, & & $0.11^{* * *}$ & $0.09 * *$ & $0.10^{* *}$ & 0.00 \\
\hline cleaning services & & $(0.030)$ & $(0.029)$ & $(0.032)$ & $(0.069)$ \\
\hline Controls & Yes & Yes & Yes & Yes & Yes \\
\hline$N$ & 17,672 & 17,192 & 17,192 & 10,427 & 6765 \\
\hline Pseudo $\mathrm{R}^{2}$ & 0.09 & 0.10 & 0.09 & 0.09 & 0.14 \\
\hline
\end{tabular}

${ }^{1}$ Standard errors in parentheses. Significance: ${ }^{*} p<0.05,{ }^{* *} p<0.01,{ }^{* * *} p<0.001$. Logistic models with robust errors controlling for gender, age (age groups in years), employer/firm experience (years), employer/firm experience squared (years ${ }^{2}$ ), migration background, marital status, part-time work (less than $20 \mathrm{~h}$ /week), region (Bundesland) of residence, residence relocation after education attainment, children living in household, strong career orientation, horizontal mismatch (partial or total occupational change). Weighted results. Data: BIBB/BAuA Employment Survey 2018, authors' own calculations. 
Regarding fields of education, M2 showed that fields offered different payoffs in terms of adequate jobs. Compared to the very specific field of medical and non-medical health care (1), the majority of other (less specific) fields (like commerce and trade (8); business management (9); and organization and gastronomy, food industry, and tourism (6)) performed worse in avoiding overeducation. Only the educational fields of IT and natural sciences (11), manufacturing (3), and technology production (4), which were also considered as occupationally specific, did not lead to significantly higher overeducation risks. This evidence is therefore consistent with $\mathrm{H} 2$. In addition, M2a and M2b indicated that field effects were not to be found indistinctly at the vocational and academic level of education. Whereas building and interior construction (5) and gastronomy, food industry, and tourism (6) led to higher overeducation risks at both the vocational and the academic level, the overeducation-enhancing effect of commerce and trade (8), and the effect of business management and organization (9) seemed to be driven by degrees at the vocational or the academic level, respectively.

Moreover, M2b showed that academic degrees in manufacturing (3) were 22 percentage points more likely to be overeducated than people in the reference category of health (1). On the other hand, M2a showed that vocational degrees in manufacturing (3) did not seem to significantly differ in the overeducation probability compared to health (1).

Lastly, both academic and vocational degrees in the specific field of IT and natural sciences (11) were associated with not being overeducated for a held job, as there are no statistically significant differences in overeducation risks compared to the degrees in health. In addition, it is worth mentioning that, according to the pseudo $\mathrm{R}^{2}$, the predictions for overeducation had a better fit for academically than for vocationally educated workers. In this sense, the predictive power of fields of education were of more relevance for academic degrees than for vocational degrees (at least when using the similar categorization of fields). Comparisons with previous results are, however, not straightforward because analyses of overeducation have focused only on the group of academically educated workers.

\subsection{Social Background}

$\mathrm{H} 3$ is used to address to the question of whether there is a social gap in overeducation when level and field education are controlled for. Table 3 contains stepwise logistic regression models used to test this hypothesis. M3 included the dummy variable measuring social origins (workers originating in the high salariat class) and controlled for several confounds. This model indicated a negative relationship between coming from the high salariat background and the probability of overeducation, but the coefficient of high salariat is not statistically significant. This could have led to the assumption that risks of overeducation do not vary across social backgrounds (holding the control variables constant), as would be predicted by the modernization hypothesis. However, when the educational level of workers was added (M4), the coefficient was statistically significant, pointing to a social gap in overeducation when controlling for educational level. Moreover, fields of education represent a horizontal dimension of social stratification. Following social stratification arguments based on the origin-education-destination triangle, education should be considered in its vertical (level) and its horizontal dimension (fields), given that social origins affect both educational level and field. Thereby, M5 additionally controlled for the fields of education. Workers originating from the high salariat class were three percentage points less likely to be overeducated than workers originating from the other, less privileged classes, holding level and field of education and other control variables constant. This evidence is in line with H3. Even though the social gap in overeducation was very small, it implied that the effect of social origin was not fully mediated through education and that social background still mattered to a limited extent for adequate job positions among workers with similar degrees. 
Table 3. Logit regression models of overeducation (subjective indicator) on social background, educational level, and educational fields (AME) ${ }^{1}$.

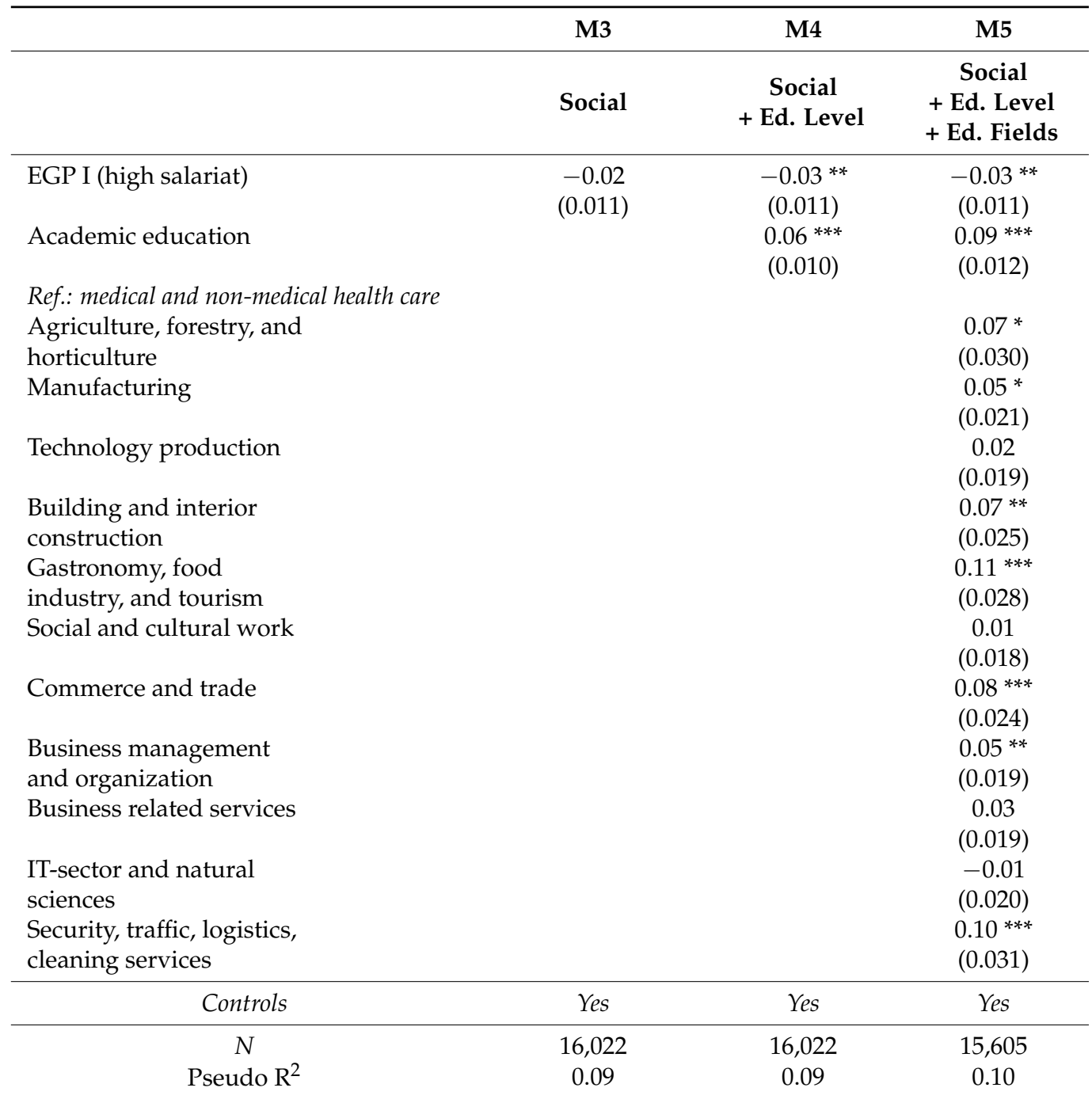

${ }^{1}$ Standard errors in parentheses. Significance: ${ }^{*} p<0.05,{ }^{* *} p<0.01,{ }^{* * *} p<0.001$. Logistic models with robust errors controlling for gender, age (age groups in years), employer/firm experience (years), employer/firm experience squared (years ${ }^{2}$ ), migration background, marital status, part-time work (less than $20 \mathrm{~h} /$ week), region (Bundesland) of residence, residence relocation after education attainment, children living in household, strong career orientation, horizontal mismatch (partial or total occupational change). Weighted results. Data: BIBB/BAuA Employment Survey 2018, authors' own calculations.

\subsection{Social Background Inequalities across Levels and Fields of Education}

Figure 2 presents information regarding the social gap in overeducation by breaking down the data to show whether social background is related to overeducation risks for workers with vocational education to the same extent as for workers with academic education. Both sides of Figure 2a,b show the predicted probability of overeducation for the combinations of social background and educational level.

Figure 2a is based on an extension of the logistic model M4 that included an interaction between social origin and educational field. It shows that offspring of less privileged EGP classes made worse use of the acquired academic degrees (i.e., degree-job mismatches), showing a significantly higher probability of being overeducated than offspring of the high salariat, i.e., the most privileged social class $(0.287-0.228=0.059 ; p<0.05)$. The difference in overeducation risks appeared to be only slightly smaller comparing vocationally educated workers from both class categories $(0.220-0.188=0.032 ; p<0.05)$. The difference in overeducation risks for vocationally and academically educated workers were not significant in statistical terms (second difference $0.032-0.059=-0.023 ; p=0.236$ ). This 
speaks against $\mathrm{H} 4 \mathrm{a}$ and $\mathrm{H} 4 \mathrm{~b}$, which postulated that social background inequalities should differ significantly across levels of education.

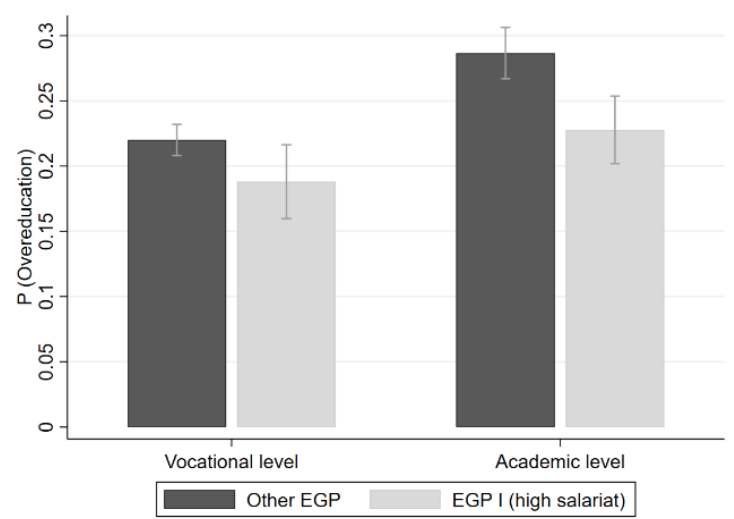

(a)

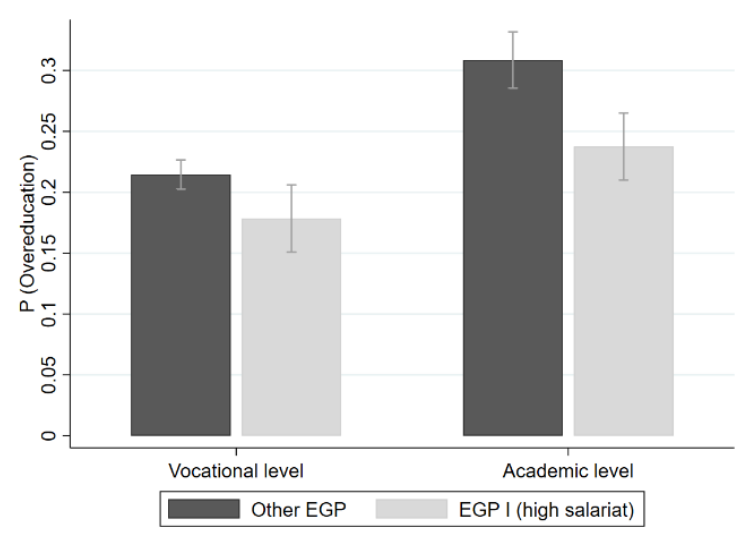

(b)

Figure 2. (a) Predicted probability of overeducation (subjective indicator) (AME) (no control for fields of education); (b) Predicted probability of overeducation (subjective indicator) (AME) (controlling for fields of education). Standard error bars at the 95-percent level. The results are based on logistic regression models adjusted for all the remaining control variables (see Section 3.3). Weighted results. Data: BIBB/BAuA Employment Survey 2018, authors' own calculations.

Figure $2 \mathrm{~b}$ adds fields of education to the logistic regression used for Figure $2 \mathrm{a}$. It appeared that the difference (i.e., the social background effect) became even larger for workers with academic educations: workers from less privileged classes showed a significantly lower probability of being overeducated than workers from the high salariat backgrounds $(0.309-0.238=0.071 ; p<0.05)$. For workers with vocational degrees, the inequality remained similar $(0.215-0.178=0.036 ; p<0.05)$. However, the social gap in overeducation did not significantly differ across educational levels (second difference $0.036-0.071=-0.035 ; p=0.132$ ), meaning that the evidence does not support H4a or H4b. In other words, social background appeared relevant in reducing overeducation risks in both levels of education (vocationally and academically educated workers).

Social background inequalities across different fields of education can be seen in Figures 3 and 4. Since the present article understands educational degrees both by level and by field, field-specific social inequalities in overeducation are analyzed separately for academic and vocational education. Figure 3 refers to the worker group with vocational education and it shows on the left side (Figure 3a) the overeducation probability for each combination of field and social background. The right side (Figure $3 b$ ) tests whether the differences in the probability of overeducation by social background are statistically significant across all considered fields. The results for vocationally educated workers showed that no social gaps in overeducation appeared in any fields of education.

The results shown in Figure 4 for academically educated workers reveal a different pattern: Figure $4 \mathrm{~b}$ shows that inequality in overeducation risk by social background differed significantly in some fields. The difference in the probability of overeducation between more privileged and less privileged social classes were negative (lower for more privileged EGP I class) and statistically significant (at the 5-percent level) among workers with academic degrees in the fields of agriculture, forestry, and horticulture (2), building and interior construction (5), and security, traffic, logistic, and cleaning (12). In the other fields the probability of overeducation did not significantly differ between more privileged and less privileged social classes (the 95-percent confidence intervals overlap with the 0 line, indicating no statistically significant difference in the probability of overeducation between EGP classes). This pattern indicates that social inequality in overeducation was 
larger in the three aforementioned fields. However, it is doubtful that especially those fields are the most general ones.

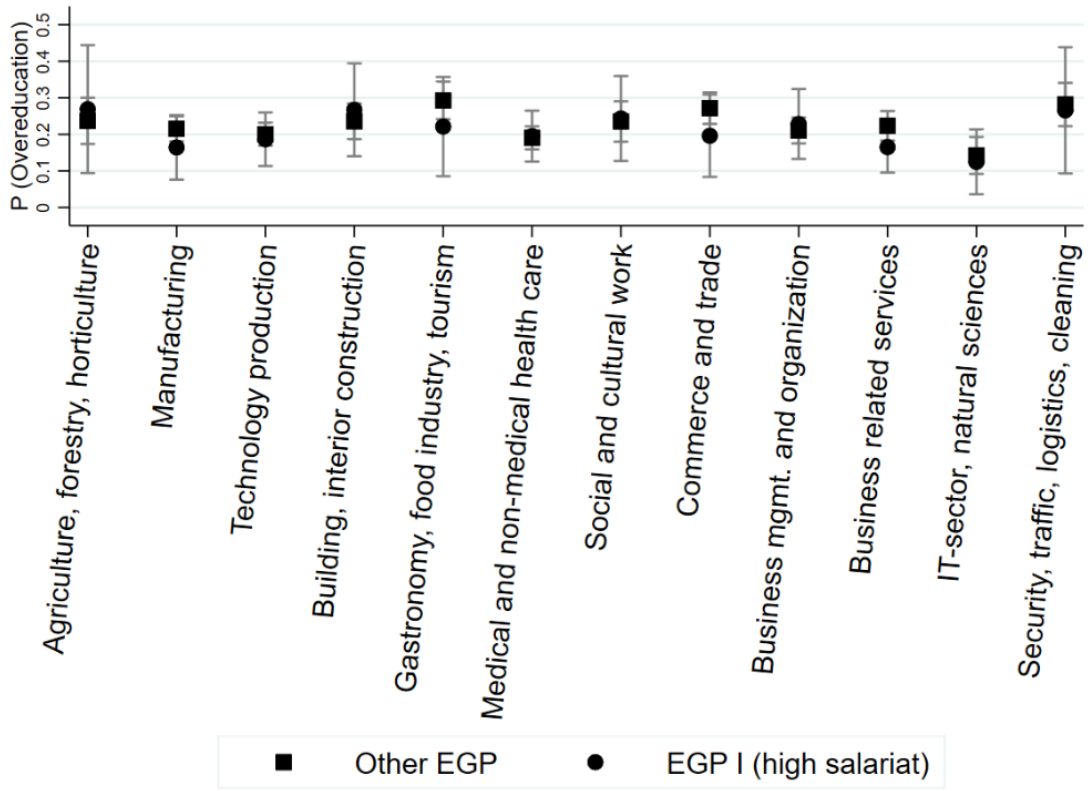

(a) Vocationally educated workers

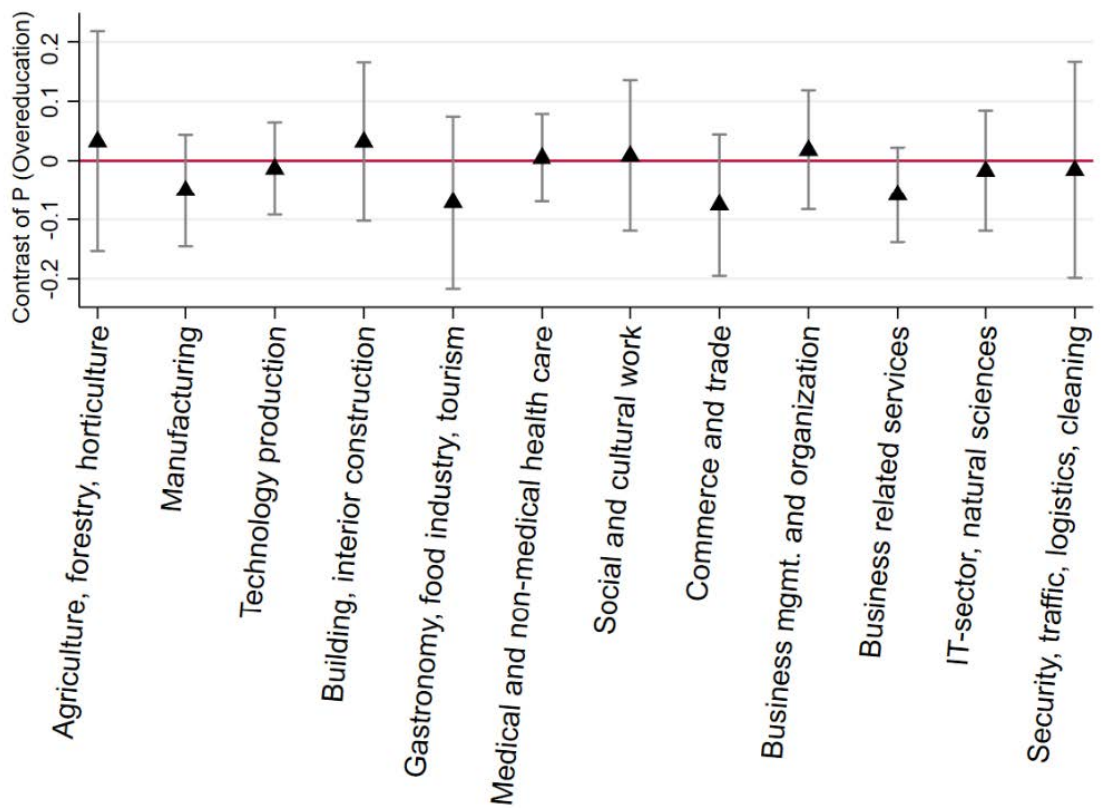

(b) Difference in overeducation probability for each field by social background

Figure 3. (a) Predicted probability of overeducation (subjective indicator) (AME) within vocationally educated workforce for each combination of educational field and social background; (b) social background differences (EGP I high salariat-other EGP) of predicted probability of overeducation for each educational field. Confidence intervals at 95-percent level. Weighted results. Data: BIBB/BAuA Employment Survey 2018, authors' own calculations. 


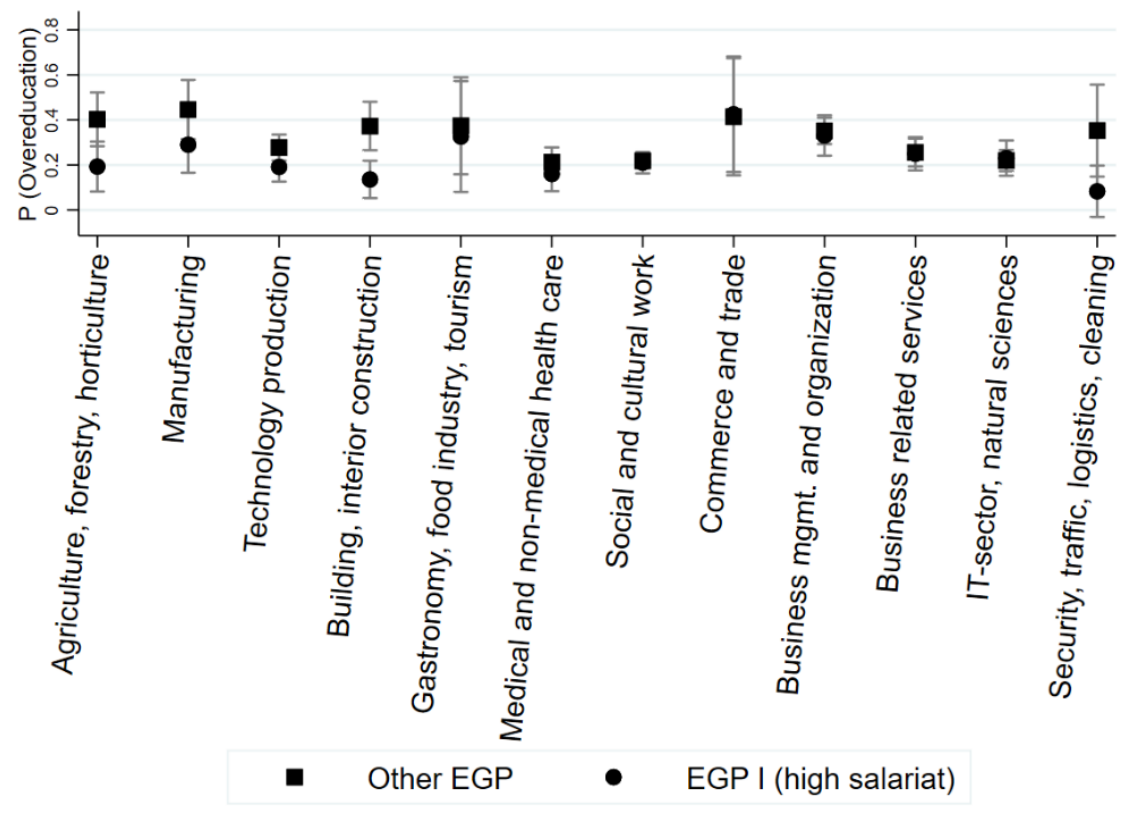

(a) Academically educated workers

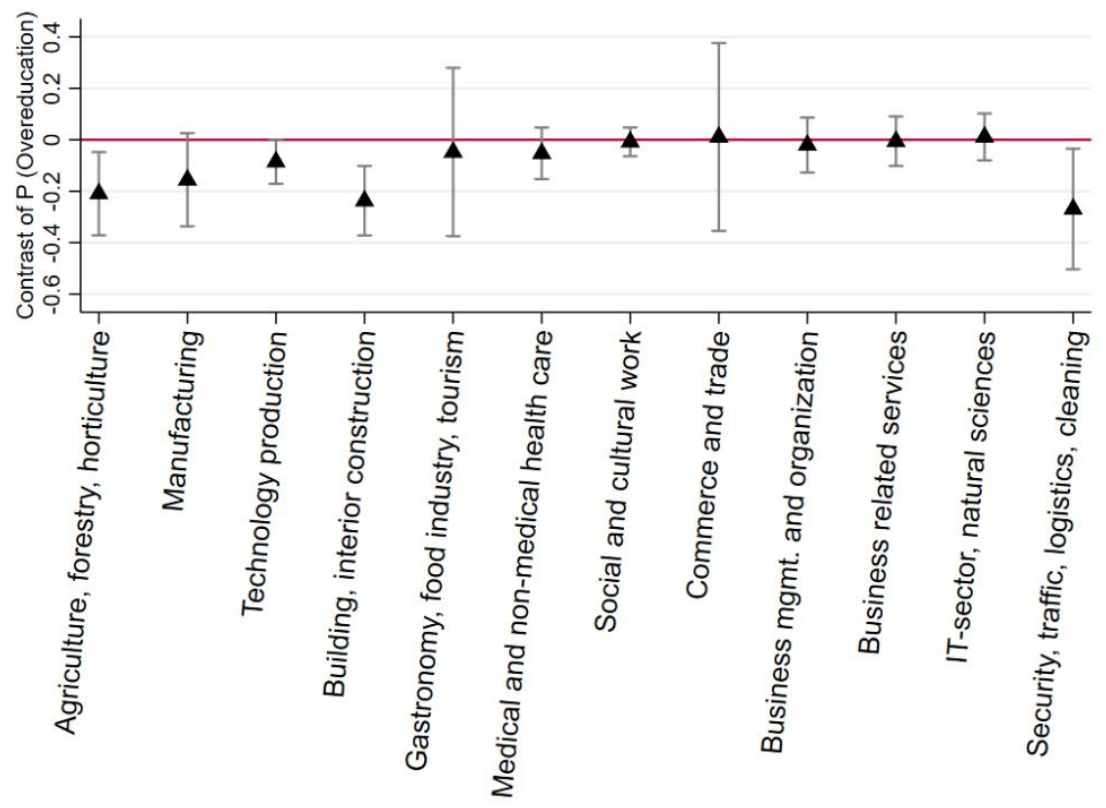

(b) Difference in overeducation probability for each field by social background

Figure 4. (a) Predicted probability of overeducation (subjective indicator) (AME) within academically educated workforce for each combination of educational field and social background; (b) social background differences (EGP I high salariat-other EGP) of predicted probability of overeducation. Confidence intervals at 95-percent level. Weighted results. Data: BIBB/BAuA Employment Survey 2018, authors' own calculations.

The implications for the test of $\mathrm{H} 5$ are multiple. First, no differences in the social gap in overeducation across educational fields appeared for vocational education degrees, but differences did appear for some academic degrees. Second, even if some field-related differences appeared for the group of workers with degrees at the academic level, these different were not in the more general fields that seemed to matter in explaining those differences. In this sense, the evidence does not support $\mathrm{H} 5$, since $\mathrm{H} 5$ explicitly suggested the social gap in overeducation would be lower in specific fields, i.e., the social gap would 
be larger in general fields. It is thereby reasonable to cautiously conclude that no differences in the magnitude of social background inequalities across specific and general fields of education can be observed.

\section{Discussion and Conclusions}

The results of the main analyses point to mixed evidence for the interrelatedness of overeducation, educational background, and social background.

First, the evidence supports $\mathrm{H} 1 \mathrm{~b}$ predicting higher overeducation risks among academically educated workers (e.g., with university degrees) than among workers with vocational education. This is in accordance with previous evidence of overeducation (Rohrbach-Schmidt and Tiemann 2011) and with seminal work characterizing the German labor market as highly stratified and vocationally oriented (Allmendinger 1989; Müller and Shavit 1998; Solga and Konietzka 2000). In that context, vocational degrees perform better than academic degrees in preventing overeducation, controlling for specific field effects, indicating that the supply of highly educated workers exceeds the availability of adequate jobs. This interpretation of an oversupply of highly educated workforce resulting in more overeducation is in line with findings that consider several European countries with different education and labor systems (Davia et al. 2017; Verhaest and Van der Velden 2013). Moreover, this interpretation is consistent with the view that demand and supply conditions within the labor market are crucial in explaining country differences in overeducation rates (Verhaest et al. 2017; Verhaest and Van der Velden 2013). In turn, other countries with stronger imbalances in the supply and demand of education, like Spain, show higher overeducation rates than Germany (Capsada-Munsech 2020).

Second, overeducation risks also vary across fields of education as proposed in $\mathrm{H} 2$, with more occupationally specific fields leading to a higher probability of adequate job allocation, and are thus in line with earlier findings within the German and other European contexts (Verhaest and Van der Velden 2013). Moreover, the evidence supports the pivotal hypothesis of this article, the existence of a social gap in overeducation controlling for education (H3), even though the magnitude of this gap is very modest. The social gap in overeducation seems to support both the persistent inequality hypothesis (Shavit and Blossfeld 2003) and arguments in favor of an effectively maintained inequality (Lucas 2001), which might intensify in educational expansion processes, when education becomes more common and increasingly positional (Bol 2015; Di Stasio et al. 2016). In this sense and following the job competition theory, individuals' relative level of education is particularly important in a context of expanding educational levels to preserve high positions within the labor queue and to avoid overeducation.

Third, the gap in overeducation related to social background does not seem to differ systematically across educational levels $(\mathrm{H} 4 \mathrm{a} / \mathrm{H} 4 \mathrm{~b})$ or across more specific or general fields of education (H5). Social background as well as degrees (defined as level and field) independently predicted the likelihood of an adequate job position, with no visible heterogeneity in the effect of social origin.

According to the lack of consensus on overeducation measures and the dependence of figures upon operationalization, some authors have emphasized the benefits of considering different measures in the analyses (Capsada-Munsech 2019). In Sections 2.1 and 3.1, the different measurement approaches were discussed and one advantage of the subjective indicator used for the main analyses was highlighted. That advantage is the possibility of taking workplace heterogeneity into account.

To complement the main results based on the subjective indicator, results using an alternative indicator for overeducation based on objective measures (JA) were re-run (see Appendix A). This type of comparison may contribute to a comprehensive understanding of overeducation through the lens of social stratification. The results should, however, be considered as complementary rather than as a test for robustness. Objective and subjective indicators measure the concept of education-to-job mismatch at different levels (at a given aggregated occupational level or at workplace level, respectively), and so deviations and 
especially magnitude differences from the main analyses should be taken with a grain of salt.

Measuring overeducation via an objective approach (see Section 3.1) and replicating the same procedure as in the main analyses (see Section 3.3), the main conclusions held, with some exceptions worth noting. With respect to educational level (H1), the objective indicator also showed a higher incidence of overeducation in the group of academically educated workers. The effect of academic education on overeducation were, however, notably stronger when using the objective indicator measuring mismatch at the occupational level. Thus, workers with academic degrees had, on average, a 30-percentage point higher probability (vs. eight-percentage point higher based on the subjective indicator) of overeducation risk than vocationally educated workers, controlling for fields of education (see M1 from Table A1 in Appendix A).

Regarding fields of education, the main hypothesis that specific fields are more likely to avoid overeducation (H2) held. However, the variation in overeducation likelihood across fields was larger when using the objective indicator (see M2 from Table A1 in Appendix A). That was the case, for example, for business-related services (15- vs. 4-percentage-point higher probability), business management and organization (11 vs. 6 percentage points), and social and cultural work (13 vs. 4 percentage points). The difference for the field of IT and natural sciences became statistically significant due to the relevance in explaining overeducation of academically educated workers (10-percentage-point higher probability of overeducation than academically educated workers in the field of health). In general, this pattern is consistent with recent comparative evidence suggesting that objective indicators show larger variations in overeducation across fields than subjective indicators show, which provides in turn more conservative results (Capsada-Munsech 2019).

Moreover, evidence based on the objective indicator also supported the existence (in the same magnitude) of a social gap in overeducation controlling for education, as suggested in H3 (see Table A2 in Appendix A). Again, this social inequality in adequate job positions did not significantly vary across level and fields of degrees as predicted in $\mathrm{H} 4 \mathrm{a} / \mathrm{H} 4 \mathrm{~b}$ and $\mathrm{H} 5$ (see Figures A1 and A2 in Appendix A, respectively). One notable exception was the field of medical and non-medical health care in the group of academically educated workers (see Figure A2 in Appendix A). In that case, the probability of overeducation significantly differed between high salariat and other EGP social classes. This is surprising given the rationale followed in H5, i.e., that in specific fields of education social background should play a minor role in avoiding overeducation risks. This does not seem to be the case, at least for the case of academic degrees in health care and when measuring overeducation through a JA approach.

From a general perspective, all the results in this article highlight the relevance of ascribed characteristics in reducing overeducation risks. Furthermore, and apart from social origin effects, academic degrees in certain general fields are also more likely to lead to inadequate jobs. However, the analyses include several limitations.

Social background was measured based on the parental EGP class schema, a wellestablished indicator to measure social classes. In addition to parental class, social background entails different components (like for example parental education) that may have distinctive effects on educational outcomes of the offspring and, more concretely, on overeducation (Capsada-Munsech 2015). We thereby captured only one of several dimensions of social origin that may be relevant for education-to-job matches. The mechanisms underlying those social origins effects are discussed exclusively on theoretical grounds based on prior research (e.g., Erdsiek 2016), since they cannot be analyzed with the data at hand and are outside of the scope of this article. Nevertheless, the present article offers a comprehensive analysis of overeducation that considers not only academic but also vocational degrees, thereby expanding the understanding to the quantitatively most important worker group that has been often overlooked in overeducation research. Additionally focusing on vocational degrees is crucial given the consensus in comparative studies suggesting 
that vocationally oriented countries show lower overeducation rates (Di Stasio et al. 2016; Verhaest and Van der Velden 2013).

Furthermore, due to possible self-selection problems (Berlingieri and Zierahn 2014), it cannot be claimed that the relationship between fields and overeducation can be interpreted in a causal way. In the same vein, educational level and overeducation may be affected by unobserved heterogeneity. Moreover, it is worth mentioning that the models used in these analyses include a variable capturing horizontal mismatch (e.g., changes between acquired education/training occupation and current occupation). Recent evidence suggested considering horizontal and vertical mismatch as strongly interrelated phenomena (Salas-Velasco 2021) and highlighted the role of mismatches of occupational skills in explaining overeducation wage penalties particularly of vocationally educated workers (Kracke et al. 2018). Consequently, horizontal mismatches should account for a relevant part of overeducation risks, as the specific human capital acquired through formal educational qualifications cannot be used, or can be only partially used, in case of a total or partial occupational change. Thus, by presenting results of overeducation controlling for horizontal mismatches, the results of the present analyses uncover relationships between educational degrees, social background, and adequate jobs that cannot be explained by mismatches between current occupation and the occupation-specific skills acquired through formal education.

As a main contribution, this article provides a multi-perspective novelty. It reveals evidence that degrees at the vocational level are more likely to lead to adequate jobs. It also confirms recent evidence asserting that occupation-specific fields of education provide better chances to avoid overeducation. Furthermore, ascribed characteristics explain some of the risk of overeducation, over and above the mediating mechanisms of educational level and field. Offspring of the high salariat in Germany are slightly more likely to make use of attained degrees to achieve a desirable adequate position on the labor market, in the sense that they use the same degrees on the labor market more profitably than the offspring of less privileged classes. Thus, the social gap in overeducation may explain recent results in social stratification research that shows social background effects on income among college graduates in the United States, meaning that college degree is not enough to erase the influence of social origin on labor market income (Witteveen and Attewell 2020).

This article offers additional merits from a social stratification perspective, considering an outcome that has received little attention in the literature so far. The theoretical approach of the origin-education-destination triangle used in social stratification research is thus extended by proposing overeducation as a desirable labor market outcome directly influenced by the social background of workers. The results give preliminary insight into how educational degrees and social background lead to adequate jobs. More research can build on these results.

First, the mechanisms behind the results, integrating both levels of education and different fields, should be further elaborated. Given that job allocation processes evolve in dynamic contexts of ongoing educational expansions and digitization trends on the labor market, bringing a dynamic perspective of social inequalities into the investigation of education-job matches appears especially promising.

Second, a more comprehensive study would extend the analyses to other countries that are either very similar to Germany or represent mostly different cases. From this perspective, a comparison with Switzerland, Austria, or Denmark, which also constitute "coordinated market economies" (Hall and Soskice 2001) and have institutionalized a dual training system, would be instructive. A subsequent question is to what extent the results of liberal market economies such as the United Kingdom or the United States differ significantly from Germany. This would provide further insight into the external validity of the findings presented in this article.

Funding: This research received no external funding.

Institutional Review Board Statement: Not applicable. 
Informed Consent Statement: Not applicable.

Data Availability Statement: This article uses data from the BIBB/BAuA Employment Survey of the Working Population on Qualification and Working Conditions in Germany 2018, https: / / doi.org/10 $.7803 / 501.18 .1 .1 .10$, accessed on 19 August 2021. The survey was conducted by the Federal Institute for Vocational Education and Training (BIBB) and the Federal Institute for Occupational Safety and Health (BAuA). Data access is provided via a Scientific-Use-File of the Research Data Centre at the Federal Institute for Vocational Education and Training (BIBB-FDZ).

Acknowledgments: The author wishes to thank the academic editor, three anonymous reviewers, Christian Ebner and Johannes Lünser for valuable comments on earlier versions of this article.

Conflicts of Interest: The author declares no conflict of interest.

\section{Appendix A}

Table A1. Logit regression models of overeducation (objective indicator) on educational level and educational fields (AME) ${ }^{1}$.

\begin{tabular}{|c|c|c|c|c|c|}
\hline & Mo & M1 & M2 & M2a & M2b \\
\hline & Ed. Level & $\begin{array}{l}\text { Ed. Level } \\
+ \text { Fields }\end{array}$ & Fields & $\begin{array}{l}\text { Fields, only } \\
\text { Vocational }\end{array}$ & $\begin{array}{c}\text { Fields, only } \\
\text { Academic }\end{array}$ \\
\hline Academic education & $\begin{array}{l}0.28^{* * *} \\
(0.009)\end{array}$ & $\begin{array}{l}0.30^{* * *} \\
(0.012)\end{array}$ & & & \\
\hline \multicolumn{6}{|c|}{ Ref.: medical and non-medical health care } \\
\hline Agriculture, forestry and & & $0.15^{* * *}$ & $0.13^{* * *}$ & $0.08^{* *}$ & $0.35^{* * *}$ \\
\hline horticulture & & $(0.030)$ & $(0.029)$ & $(0.031)$ & $(0.057)$ \\
\hline \multirow[t]{2}{*}{ Manufacturing } & & $0.09^{* * *}$ & $0.06^{* *}$ & $0.04^{*}$ & $0.28^{* * *}$ \\
\hline & & $(0.020)$ & $(0.019)$ & $(0.019)$ & $(0.058)$ \\
\hline \multirow[t]{2}{*}{ Technology production } & & $0.05^{* *}$ & $0.05^{* *}$ & 0.03 & $0.12 * *$ \\
\hline & & $(0.017)$ & $(0.016)$ & $(0.018)$ & $(0.039)$ \\
\hline Building and interior & & $0.06 *$ & $0.04 *$ & 0.03 & $0.13^{* *}$ \\
\hline construction & & $(0.021)$ & $(0.020)$ & $(0.022)$ & $(0.047)$ \\
\hline Gastronomy, food & & $0.07 * *$ & 0.02 & 0.03 & $0.29^{* * *}$ \\
\hline industry, and tourism & & $(0.024)$ & $(0.020)$ & $(0.020)$ & $(0.083)$ \\
\hline \multirow[t]{2}{*}{ Social and cultural work } & & 0.01 & $0.13^{* * *}$ & $0.07^{* *}$ & 0.04 \\
\hline & & $(0.014)$ & $(0.015)$ & $(0.024)$ & $(0.031)$ \\
\hline \multirow[t]{2}{*}{ Commerce and trade } & & $0.05 *$ & -0.00 & 0.01 & $0.40^{* * *}$ \\
\hline & & $(0.020)$ & $(0.017)$ & $(0.016)$ & $(0.094)$ \\
\hline Business management & & $0.09^{* * *}$ & $0.11^{* * *}$ & 0.02 & $0.28^{* * *}$ \\
\hline and organization & & $(0.016)$ & $(0.017)$ & $(0.016)$ & $(0.039)$ \\
\hline \multirow[t]{2}{*}{ Business related services } & & $0.11^{* * *}$ & $0.15^{* * *}$ & 0.02 & $0.31^{* * *}$ \\
\hline & & $(0.017)$ & $(0.018)$ & $(0.017)$ & $(0.038)$ \\
\hline IT-sector and natural & & 0.01 & $0.11^{* * *}$ & -0.03 & $0.10^{* *}$ \\
\hline sciences & & $(0.017)$ & $(0.020)$ & $(0.019)$ & $(0.037)$ \\
\hline Security, traffic, logistics, & & $0.07 * *$ & 0.02 & 0.00 & $0.48^{* * *}$ \\
\hline cleaning services & & $(0.025)$ & $(0.023)$ & $(0.021)$ & $(0.073)$ \\
\hline Controls & Yes & Yes & Yes & Yes & Yes \\
\hline$N$ & 17,883 & 17,401 & 17,401 & 10,571 & 6830 \\
\hline Pseudo $\mathrm{R}^{2}$ & 0.14 & 0.15 & 0.07 & 0.07 & 0.11 \\
\hline
\end{tabular}

${ }^{1}$ Standard errors in parentheses. Significance: ${ }^{*} p<0.05,{ }^{* *} p<0.01,{ }^{* * *} p<0.001$. Logistic models with robust errors controlling for gender, age (age groups in years), employer/firm experience (years), employer/firm experience squared (years ${ }^{2}$ ), migration background, marital status, part-time work (less than $20 \mathrm{~h}$ /week), region (Bundesland) of residence, residence relocation after education attainment, children living in household, strong career orientation, horizontal mismatch (partial or total occupational change). Weighted results. Data: BIBB/BAuA Employment Survey 2018, authors' own calculations. 
Table A2. Logit regression models of overeducation (objective indicator) on social background, educational level, and educational fields (AME) ${ }^{1}$.

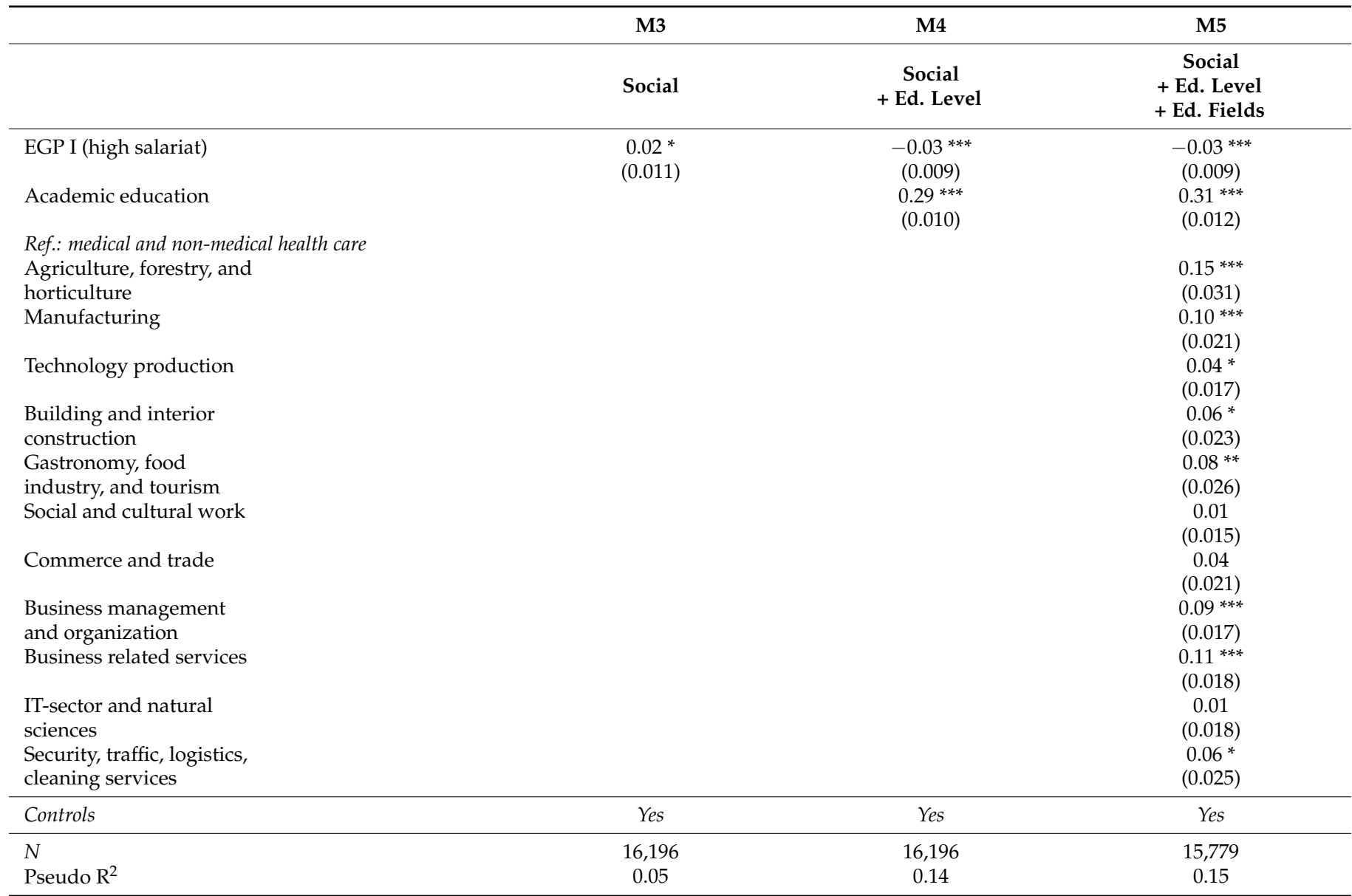

${ }^{1}$ Standard errors in parentheses. Significance: ${ }^{*} p<0.05,{ }^{* *} p<0.01,{ }^{* * *} p<0.001$. Logistic models with robust errors controlling for gender, age (age groups in years), employer/firm experience (years), employer/firm experience squared (years ${ }^{2}$ ), migration background, marital status, part-time work (less than $20 \mathrm{~h}$ /week), region (Bundesland) of residence, residence relocation after education attainment, children living in household, strong career orientation, horizontal mismatch (partial or total occupational change). Weighted results. Data: BIBB/BAuA Employment Survey 2018, authors' own calculations.

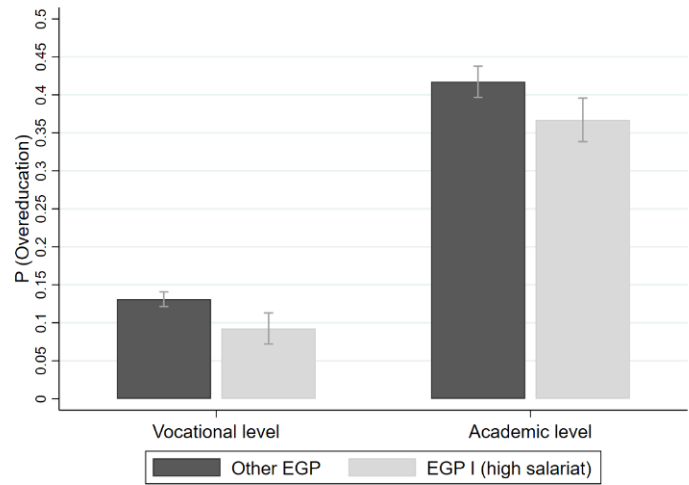

(a)

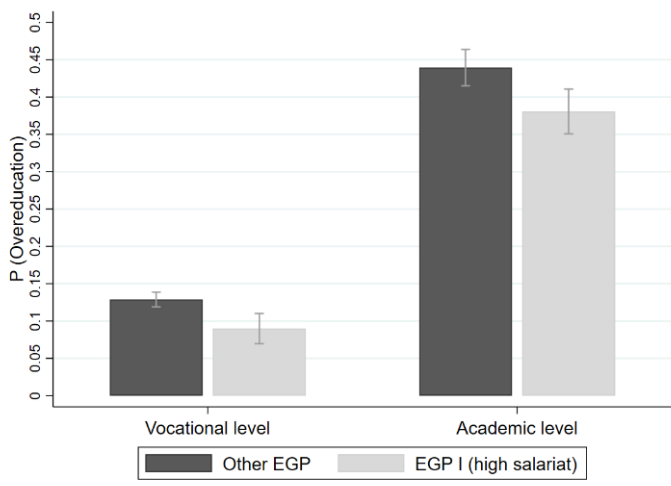

(b)

Figure A1. (a) Predicted probability of overeducation (objective indicator) (AME) (no control for fields of education); (b) Predicted probability of overeducation (objective indicator) (AME) (controlled for fields of education). Standard error bars at the 95-percent level. The results are based on logistic regression models adjusted for all the remaining control variables (see Section 3.3). Weighted results. Data: BIBB/BAuA Employment Survey 2018, authors' own calculations. 


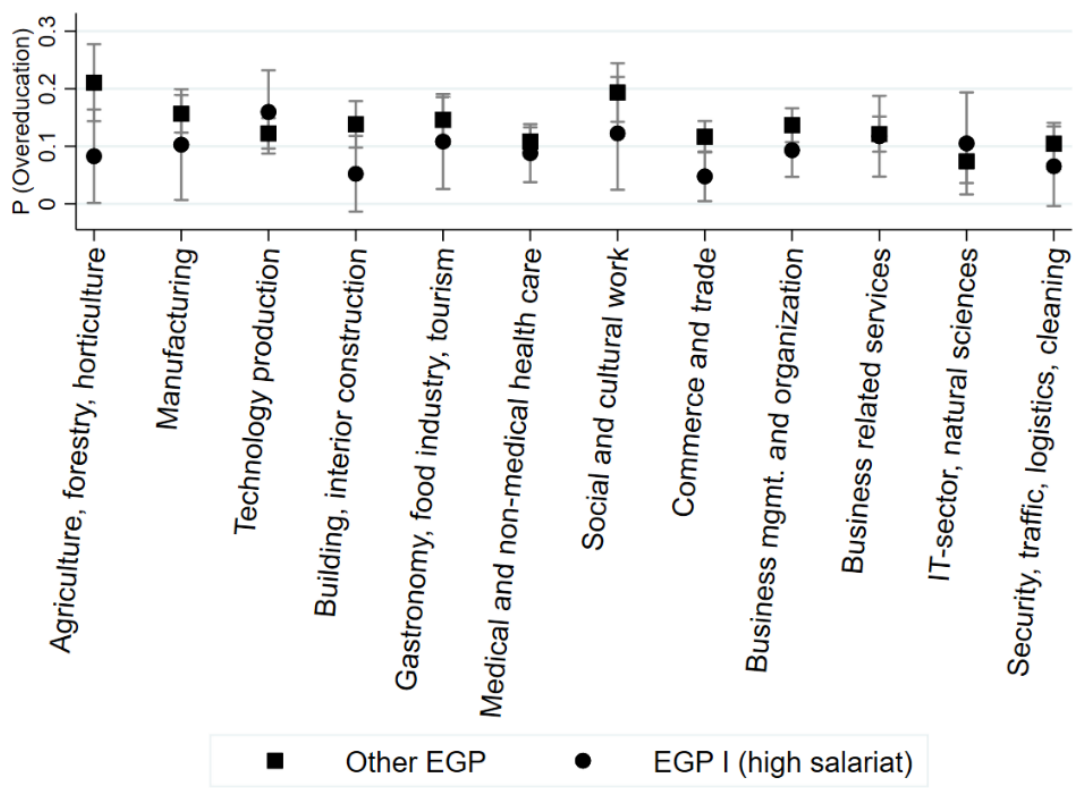

(a) Vocationally educated workers

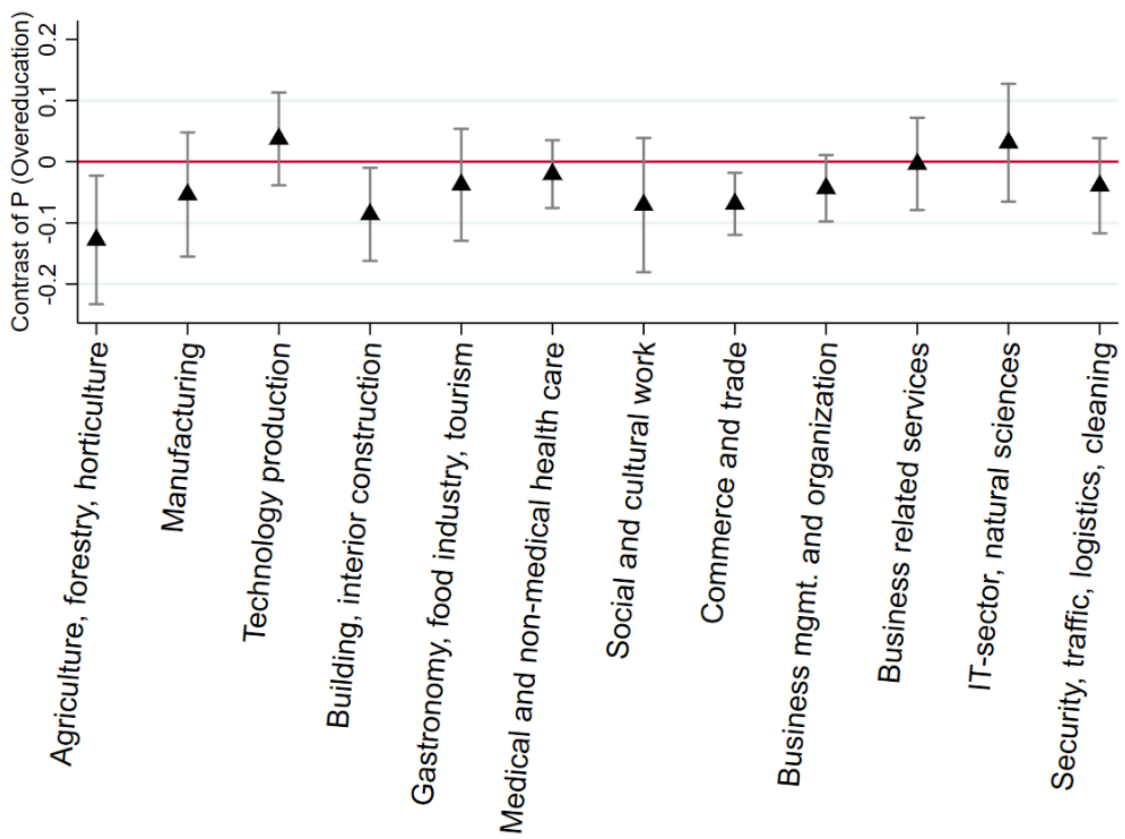

(b) Difference in overeducation probability for each field by social background

Figure A2. (a) Predicted probability of overeducation (objective indicator) (AME) within vocational education for each combination of educational field and social background; (b) Social background differences (EGP I high salariat-other EGP) of predicted probability of overeducation. Confidence intervals at 95-percent level. Weighted results. Data: BIBB/BAuA Employment Survey 2018, authors' own calculations. 


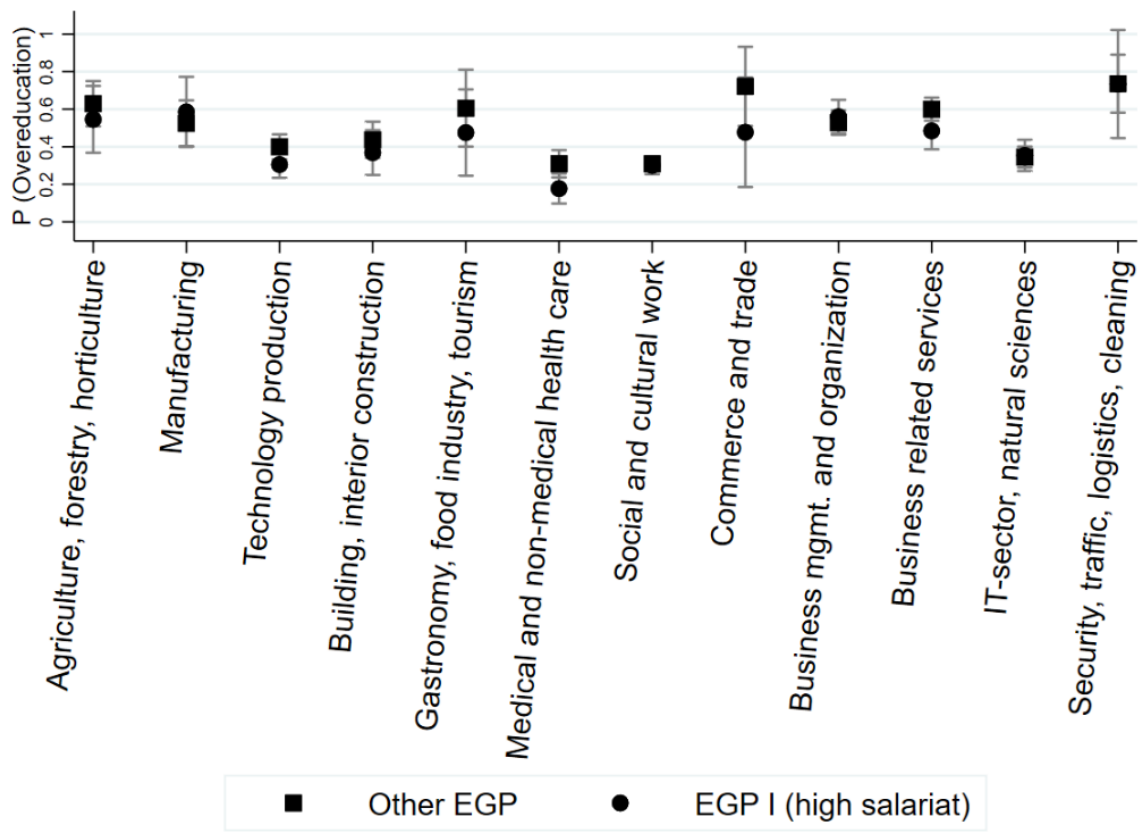

(a) Academically educated workers

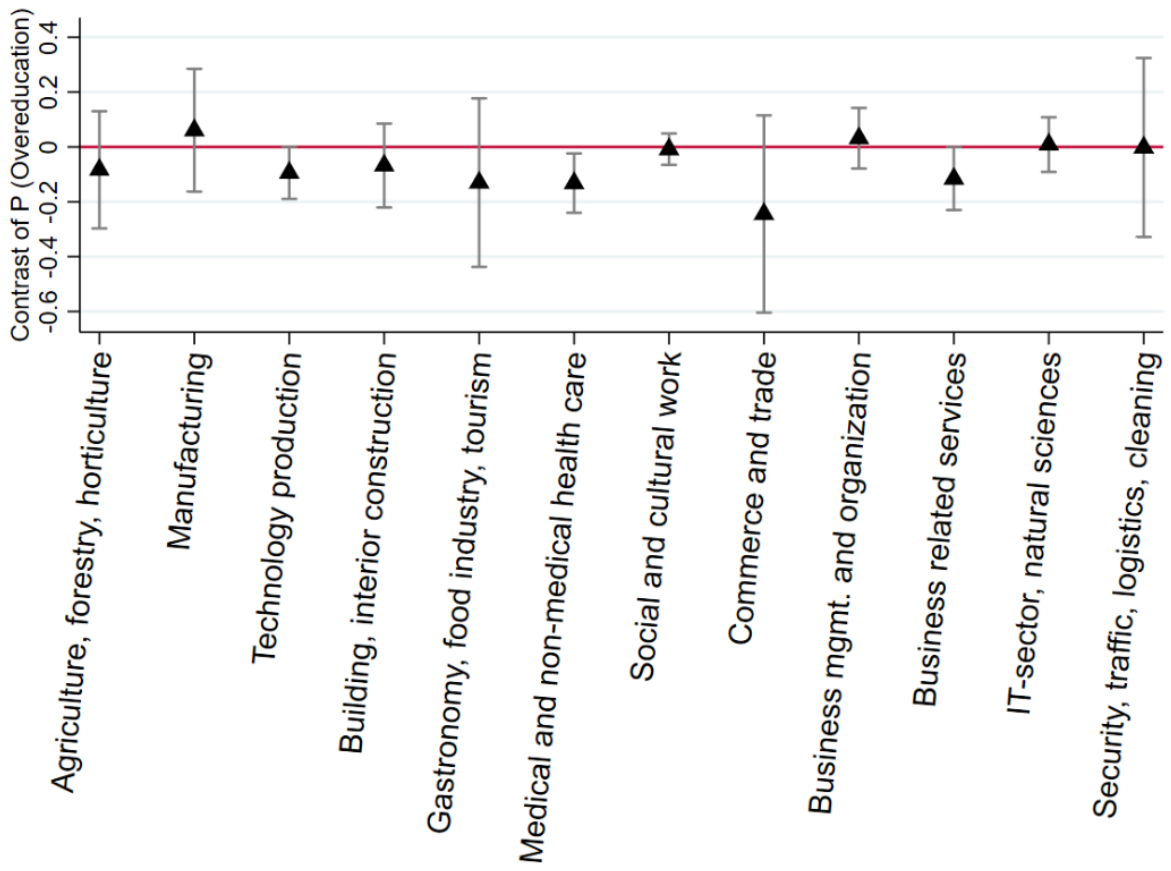

(b) Difference in overeducation probability for each field by social background

Figure A3. (a) Predicted probability of overeducation (objective indicator) (AME) within academic education for each combination of educational field and social background; (b) Social background differences (EGP I high salariat-other EGP) of predicted probability of overeducation. Confidence intervals at 95-percent level. Weighted results. Data: BIBB/BAuA Employment Survey 2018, authors' own calculations. 


\section{Notes}

1 This differentiation is especially relevant when analyzing education-job matches in the context of inequalities by social background. Individuals with the same degrees (same attained education) should, in normative terms, have similar opportunities to utilize the acquired degrees on the labor market. If, on the contrary, the assumption in the present article of a direct effect of social background on job allocation was confirmed, it would imply that the same educational credentials offer different opportunities to offspring of privileged and less privileged classes, i.e. that the same educational degrees are not sufficient to equalize opportunities for adequate jobs.

2 RM indicators are based on the statistical distribution of educational levels of workers in each occupation/occupational code to establish a threshold and consider who is and who is not overeducated (e.g., mode, mean, median, possibly plus/minus standard deviations). JA indicators are based on experts' assessments of the educational level required in each occupation, which are usually collected in national and international occupational classifications. In Germany, the current German Classification of Occupations 2010 (Klassifikation der Berufe [KldB] 2010) provides information on the educational level required in each occupation.

3 Helpful in this debate are the concepts of labor market signaling and screening. Screening theories consider educational credentials as screens. Whereas job seekers signal, employers screen on the basis of credentials (see Bills 2003 for an overview of competing theories).

4 The possibility of restricting access to occupations is in Germany additionally given by licenses, which allow exclusivity in the possibility of occupational access (Haupt 2016).

5 There are other alternative distinctions of fields of education, based for example on prestige (Klein 2016) or on a distinction between hard and soft fields (Hansen 2001).

6 The majority of research analyzing educational fields and overeducation focused on higher (academic) education. The role of educational field is likely to differ with the educational level. However, due to the scarcity of ex ante theoretical and empirical basis, we prefer to refrain from making concrete hypotheses on heterogeneous effects of specific fields of education between graduates of academic and vocational education. Possible differences will thus be explicitly reflected and discussed in the Section 4.

7 The selection in the mobile telephony sample is based on a simple random selection of mobile numbers, so that the target person is the contacted device user. In the fixed network sample a target person is, first randomly selected within the respective household using the Kish Selection Grid. Second, possible sources of selectivity limiting representativeness (e.g., lack of accessibility and non-response) are corrected by an adjustment weight, i.e., by calibrating the sample structures to those of the population with weighting factors. The structural adjustment is based on official data from the 2017 Microcensus, which represent by convention the population and the structural features in a comparable manner. After implementing a weighting model with multidimensional marginal distributions by comparing the net sample realized with the distributions of the population, an iterative weighting process results in weighting factors that adjust the realized sample to all specified target distributions with predefined accuracy and minimum variance (see Gensicke and Tschersich (2018) for further details).

8 If workers acquired several degrees, the highest level of degree was considered. In case a worker acquired several degrees at the same level, the most recently acquired educational degree was considered.

9 In order not to overload the discussion of results, the analyses based on the objective overeducation indicator (job analysis indicator) are presented as supplementary material in the Appendix A and discussed in the Section 5.

10 The fifth digit of the KldB 2010 refers to the formal requirement level of occupations and it comprises four levels to distinguish the degree of complexity of an occupation, depending on the educational level needed to perform on the job (for a similar implementation, see Kracke et al. 2018; Reichelt and Vicari 2014). For skilled activities (level 2), requirements equal the level of vocational education; for complex activities (level 3) requirement equal the level of advanced vocational training; and for highly complex activities (level 4) requirements equal the level of academic education (master's or diploma degree) (see Paulus and Matthes 2013).

11 Academic degrees refer to university of applied sciences degrees or university degrees. Vocational degrees refer to vocational training and to advanced training degrees. If workers acquired several degrees, the degree with the highest level is considered. In case a worker acquired several degrees with the same level, the most recently acquired educational degree is considered.

12 For the construction of the EGP class schema, we used additional information on occupational codes of the dataset. We also used the Stata module iskoegp developed by John Hendrickx to transform ISCO-88 occupational codes into an EGP scale, following the implementation of the classification prepared by the Research Data Center at the Federal Institute for Vocational Education and Training (BIBB-FDZ) to be found in the metadata portal (see https:/ / metadaten.bibb.de/, accessed on 4 April 2021).

13 There are different possibilities for constructing an indicator based on the EGP class schema. This categorization, which distinguishes the higher salariat instead of the whole salariat or service class (EGP class I+II, higher and lower managerial and professional occupations) from the other heterogeneous social classes has already been used in a previous analysis of the authors' schema (Bukodi and Goldthorpe 2011). Our indicator captures how belonging to the highest possible parental social class relates to workers' opportunities for obtaining desirable matched jobs. A previously conducted logistic regression without controls indicated that high salariat (EGP I) is the only class category with statistically significant lower probability of overeducation compared to the lower class of semi- and unskilled manual workers (EGP VIIa). 


\section{References}

Acemoglu, Daron, and David H. Autor. 2011. Skills, tasks and technologies: Implications for employment and earnings. Handbook of Labor Economics 4: 1043-171.

Alda, Holger, Anett Friedrich, and Daniela Rohrbach-Schmidt. 2020. Educational expansion and educational wage premiums of young male employees: A long-term analysis for West Germany 1976-2010. Social Science Research 85: 102351. [CrossRef] [PubMed]

Allen, Jim, and Rolf Van der Velden. 2001. Educational mismatches versus skill mismatches: effects on wages, job satisfaction, and on-the-job search. Oxford Economic Papers 53: 434-52. [CrossRef]

Allen, Jim, Mark Levels, and Rolf van der Velden. 2013. Skill mismatch and skill use in developed countries: Evidence from the PIAAC study. Research Centre for Education and the Labour Market (ROA). [CrossRef]

Allmendinger, Jutta. 1989. Educational systems and labor market outcomes. European Sociological Review 5: 231-50. [CrossRef]

Antonczyk, Dirk, Thomas DeLeire, and Bernd Fitzenberger. 2018. Polarization and Rising Wage Inequality: Comparing the U.S. and Germany. Econometrics 6: 20. [CrossRef]

Autor, David H., Frank Levy, and Richard J. Murnane. 2003. The skill content of recent technological change: An empirical exploration. The Quarterly Journal of Economics 118: 1279-333. [CrossRef]

Ballarino, Gabriele, Carlo Barone, and Nazareno Panichella. 2016. Social background and education in occupational attainment in Italy. In Education, Occupation and Social Origin. A Comparative Analysis of the Transmission of Socio-Economic Inequalities. Edited by Fabrizio Bernardi and Gabriele Ballarino. Northampton: Edward Elgar Publishing, pp. 82-93.

Bar Haim, Eyal, and Yossi Shavit. 2013. Expansion and inequality of educational opportunity: A comparative study. Research in Social Stratification and Mobility 31: 22-31. [CrossRef]

Barone, Carlo, and Luis Ortiz. 2011. Overeducation among European University Graduates: a comparative analysis of its incidence and the importance of higher education differentiation. Higher Education 61: 325-37. [CrossRef]

Barone, Carlo, and Steffen Schindler. 2014. Why Does Field of Study Affect Occupational Attainment? A Theoretical Approach. SSRN. [CrossRef]

Bauer, Thomas K. 2002. Educational mismatch and wages: A panel analysis. Economics of Education Review 21: 221-29. [CrossRef]

Becker, Gary S. 1962. Investment in human capital: A theoretical analysis. Journal of Political Economy 70: 9-49. [CrossRef]

Becker, Gary S. 1964. Human Capital: A Theoretical and Empirical Analysis, with Special Reference to Education. New York: National Bureau of Economic Research.

Beicht, Ursula, and Günter Walden. 2015. How socially selective is the German system of initial vocational education and training? Transitions into initial vocational training and the influence of social background. Journal of Vocational Education E Training 67: 235-55. [CrossRef]

Berlingieri, Francesco, and Daniel Erdsiek. 2012. How Relevant Is Job Mismatch for German Graduates? ZEW Discussion Paper 2012-075. Available online: https:/ / papers.ssrn.com/sol3/papers.cfm?abstract_id=2179041 (accessed on 20 August 2021). [CrossRef]

Berlingieri, Francesco, and Ulrich Zierahn. 2014. Field of Study, Qualification Mismatch, and Wages: Does Sorting Matter? ZEW Discussion Paper, No. 14-076. Mannheim: ZEW Mannheim. [CrossRef]

Bernardi, Fabrizio, and Gabriele Ballarino. 2016. Education, Occupation and Social Origin. A Comparative Analysis of the Transmission of Socio-Economic Inequalities. Northampton: Edward Elgar Publishing.

Bills, David B. 2003. Credentials, Signals, and Screens: Explaining the Relationship Between Schooling and Job Assignment. Review of Educational Research 73: 441-69. [CrossRef]

Blau, Peter M., and Otis D. Duncan. 1967. The American Occupational Structure. New York: Wiley.

Bol, Thijs. 2015. Has education become more positional? Educational expansion and labour market outcomes, 1985-2007. Acta Sociologica 58: 105-20. [CrossRef]

Bol, Thijs, and Kim A. Weeden. 2014. Occupational closure and wage inequality in Germany and the United Kingdom. European Sociological Review 31: 354-69. [CrossRef]

Bol, Thijs, Christina Ciocca Eller, Herman G. van de Werfhorst, and Thomas A. DiPrete. 2019. School-to-Work Linkages, Educational Mismatches, and Labor Market Outcomes. American Sociological Review 84: 275-307. [CrossRef]

Boll, Christina, and Julian S. Leppin. 2016. Differential Overeducation in East and West Germany: Extending Frank's Theory on Economic Returns Changes the Picture of Disadvantaged Women. LABOUR 30: 455-504. [CrossRef]

Borgna, Camilla, Heike Solga, and Paula Protsch. 2019. Overeducation, Labour Market Dynamics, and Economic Downturn in Europe. European Sociological Review 35: 116-32. [CrossRef]

Bouchet-Valat, Milan, Camille Peugny, and Louis-André Vallet. 2016. Inequality of Educational Returns in France. Some Evidence of Change in the Relative Importance of the Effect of Education and Social Background on Occupational Careers. Notes et Documents de l'OSC, no 2016-5. Paris: Observatoire Sociologique du Changement.

Bourdieu, Pierre. 1984. Distinction. A Social Critique of the Judgement of Taste. Cambridge: Harvard University Press.

Breen, Richard, and Jan O. Jonsson. 2007. Explaining Change in Social Fluidity: Educational Equalization and Educational Expansion in Twentieth-Century Sweden. American Journal of Sociology 112: 1775-810. [CrossRef]

Breen, Richard, and Ruud Luijkx. 2004. Social Mobility in Europe between 1970 and 2000. Social Mobility in Europe. Oxford: Oxford University Press, pp. 37-77.

Breen, Richard, Ruud Luijkx, Walter Müller, and Reinhard Pollak. 2010. Long-term Trends in Educational Inequality in Europe: Class Inequalities and Gender Differences1. European Sociological Review 26: 31-48. [CrossRef] 
Büchel, Felix. 1998. Zuviel Gelernt? Ausbildungsinadäquate Erwerbstätigkeit in Deutschland. Bielefeld: Bertelsmann.

Büchel, Felix, and Harminder Battu. 2003. The theory of differential overqualification: Does it work? Scottish Journal of Political Economy 50: 1-16. [CrossRef]

Büchel, Felix, and Maarten Van Ham. 2003. Overeducation, regional labor markets, and spatial flexibility. Journal of Urban Economics 53: 482-93. [CrossRef]

Bukodi, Erzsébet, and John H. Goldthorpe. 2011. Social class returns to higher education: Chances of access to the professional and managerial salariat for men in three British birth cohorts. Longitudinal and Life Course Studies 2: 185-201. [CrossRef]

Capsada-Munsech, Queralt. 2015. The role of social origin and field of study on graduates' overeducation: The case of Italy. Higher Education 69: 779-807. [CrossRef]

Capsada-Munsech, Queralt. 2017. Overeducation: Concept, theories, and empirical evidence. Sociology Compass 11: e12518. [CrossRef]

Capsada-Munsech, Queralt. 2019. Measuring Overeducation: Incidence, Correlation and Overlaps across Indicators and Countries. Social Indicators Research 145: 279-301. [CrossRef]

Capsada-Munsech, Queralt. 2020. Overeducation, skills and social background: the influence of parental education on overeducation in Spain. Compare: A Journal of Comparative and International Education 50: 216-36. [CrossRef]

Croce, Guiseppe, and Emanuela Ghignoni. 2012. Demand and Supply of Skilled Labour and Overeducation in Europe: A Country-level Analysis. Comparative Economic Studies 54: 413-39. [CrossRef]

Croce, Guiseppe, and Emanuela Ghignoni. 2015. Educational mismatch and spatial flexibility in Italian local labour markets. Education Economics 23: 25-46. [CrossRef]

Daly, Mary C., Felix Büchel, and Greg J. Duncan. 2000. Premiums and penalties for surplus and deficit education: Evidence from the United States and Germany. Economics of Education Review 19: 169-78. [CrossRef]

Davia, María A., Seamus McGuinness, and Philip J. O'Connell. 2017. Determinants of regional differences in rates of overeducation in Europe. Social Science Research 63: 67-80. [CrossRef]

Di Stasio, Valentina, Thijs Bol, and Herman G. Van de Werfhorst. 2016. What makes education positional? Institutions, overeducation and the competition for jobs. Research in Social Stratification and Mobility 43: 53-63. [CrossRef]

Duncan, Greg, and Saul Hoffman. 1981. The incidence and wage effects of overeducation. Economics of Education Review 1: 75-86. [CrossRef]

Erdsiek, Daniel. 2016. Overqualification of graduates: assessing the role of family background. Journal for Labour Market Research 49: 253-68. [CrossRef]

Erikson, Robert, and John H. Goldthorpe. 1992. The Constant Flux: A Study of Class Mobility in Industrial Societies. Oxford: Clarendon Press.

Erikson, Robert, John H. Goldthorpe, and Lucienne Portocarero. 1979. Intergenerational Class Mobility in Three Western European Societies: England, France and Sweden. The British Journal of Sociology 30: 415-41. [CrossRef]

Fleming, Christopher M., and Parvinder Kler. 2008. I'm too clever for this job: A bivariate probit analysis on overeducation and job satisfaction in Australia. Applied Economics 40: 1123-38. [CrossRef]

Flisi, Sara, Valentina Goglio, Elena C. Meroni, Margarida Rodrigues, and Esperanza Vera-Toscano. 2017. Measuring occupational mismatch: Overeducation and overskill in Europe-Evidence from PIAAC. Social Indicators Research 131: 1211-49. [CrossRef]

Forster, Andrea G., and Thijs Bol. 2018. Vocational education and employment over the life course using a new measure of occupational specificity. Social Science Research 70: 176-97. [CrossRef] [PubMed]

Frank, Robert H. 1978. Why women earn less: The theory and estimation of differential overqualification. The American Economic Review 68: 360-73.

Freeman, Richard. 1976. The Overeducated American. Cambridge: Academic Press.

Frei, Christa, and Alfonso Sousa-Poza. 2012. Overqualification: Permanent or transitory? Applied Economics 44: 1837-47. [CrossRef]

Gensicke, Miriam, and Nikolai Tschersich. 2018. BIBB/BAuA Erwerbstätigenbefragung 2018. Methodenbericht. München: KantarPublic.

Goldthorpe, John H. 2014. The role of education in intergenerational social mobility: Problems from empirical research in sociology and some theoretical pointers from economics. Rationality and Society 26: 265-89. [CrossRef]

Granovetter, Mark. 1983. The Strength of Weak Ties: A Network Theory Revisited. Sociological Theory 1: 201-33. [CrossRef]

Green, Francis, and Golo Henseke. 2021. Europe's evolving graduate labour markets: supply, demand, underemployment and pay. Journal for Labour Market Research 55: 2. [CrossRef]

Green, Francis, and Yu Zhu. 2010. Overqualification, job dissatisfaction, and increasing dispersion in the returns to graduate education. Oxford Economic Papers 62: 740-63. [CrossRef]

Hall, Anja. 2011. Gleiche Chancen für Frauen und Männer mit Berufsausbildung? Berufswechsel, Unterwertige Erwerbstätigkeit und Niedriglohn in Deutschland, 1st ed. Berichte zur beruflichen Bildung. Bielefeld: W. Bertelsmann Verlag.

Hall, Peter, and David Soskice. 2001. An introduction to varieties of capitalism. In Varieties of Capitalism. The Institutional Foundations of Comparative Advantage. Edited by Peter Hall and David Soskice. New York: Oxford University Press.

Hall, Anja, Lena Hünefeld, and Daniela Rohrbach-Schmidt. 2020. BIBB/BAuA Employment Survey of the Working Population on Qualification and Working Conditions in Germany 2018. Edited by Research Data Center at BIBB and GESIS Cologne. Bonn: Federal Institute for Vocational Education and Training (BIBB). [CrossRef]

Hansen, Marianne N. 2001. Education and Economic Rewards. Variations by Social-Class Origin and Income Measures. European Sociological Review 17: 209-31. [CrossRef] 
Hansen, Marianne N., and Arne Mastekaasa. 2006. Social Origins and Academic Performance at University. European Sociological Review 22: 277-91. [CrossRef]

Hartog, Joop. 2000. Over-education and earnings: Where are we, where should we go? Economics of Education Review 19: 131-47. [CrossRef]

Haupt, Andreas. 2016. Erhöhen berufliche Lizenzen Verdienste und die Verdienstungleichheit? Zeitschrift für Soziologie 45: 39-56. [CrossRef]

Henseke, Golo. 2019. Against the Grain? Assessing Graduate Labour Market Trends in Germany Through a Task-Based Indicator of Graduate Jobs. Social Indicators Research 141: 809-40. [CrossRef]

Hout, Michael. 1988. More Universalism, Less Structural Mobility: The American Occupational Structure in the 1980s. American Journal of Sociology 93: 1358-400. [CrossRef]

Iannelli, Cristina, and Lindsay Paterson. 2007. Education and social mobility in Scotland. Research in Social Stratification and Mobility 25: 219-32. [CrossRef]

Jacob, Marita, Markus Klein, and Cristina Iannelli. 2015. The Impact of Social Origin on Graduates' Early Occupational DestinationsAn Anglo-German Comparison. European Sociological Review 31: 460-76. [CrossRef]

Kleibrink, Jan. 2016. Inept or Badly Matched?-Effects of Educational Mismatch in the Labor Market. Labour 30: 88-108. [CrossRef]

Klein, Markus. 2016. Educational Expansion, Occupational Closure and the Relation between Educational Attainment and Occupational Prestige over Time. Sociology 50: 3-23. [CrossRef]

Kracke, Nancy. 2016. Unterwertige Beschäftigung von AkademikerInnen in Deutschland: Die Einflussfaktoren Geschlecht, Migrationsstatus und Bildungsherkunft und deren Wechselwirkungen. Soziale Welt 67: 177-204. [CrossRef]

Kracke, Nancy, and Christina Klug. 2021. Social Capital and Its Effect on Labour Market (Mis)match: Migrants' Overqualification in Germany. Journal of International Migration and Integration. [CrossRef]

Kracke, Nancy, Malte Reichelt, and Basha Vicari. 2018. Wage Losses Due to Overqualification: The Role of Formal Degrees and Occupational Skills. Social Indicators Research 139: 1085-108. [CrossRef]

Leuven, Edwin, and Hessel Oosterbeek. 2011. Overeducation and mismatch in the labor market. In Handbook of the Economics of Education. Edited by Eric A. Hanushek, Stephen Machin and Ludger Woessmann. Amsterdam: Elsevier, vol. 4, pp. 283-326. [CrossRef]

Levels, Mark, Rolf van der Velden, and Jim Allen. 2014. Educational Mismatches and Skill Mismatches: New Empirical Tests of Old Hypotheses. Oxford Economics Papers 66: 959-82. [CrossRef]

Lucas, Samuel R. 2001. Effectively maintained inequality: Education transitions, track mobility, and social background effects. American Journal of Sociology 106: 1642-90. [CrossRef]

Mare, Robert. 1981. Change and stability in educational stratification. American Sociological Review 46: 72-87. [CrossRef]

Matthes, Britta, Holger Meinken, and Petra Neuhauser. 2015. Berufssektoren und Berufssegmente auf Grundlage der KldB 2010. In Methodenbericht. Nürnberg: Statistik der Bundesagentur für Arbeit.

McGuinnes, Seamus, Konstantinos Pouliakas, and Paul Redmond. 2018. Skill mismatch: Concepts, measurement and policy approaches. Journal of Economic Surveys 32: 985-1015. [CrossRef]

McGuinness, Seamus. 2006. Overeducation in the labour market. Journal of Economic Surveys 20: 387-418. [CrossRef]

Mize, Trenton D. 2019. Best Practices for Estimating, Interpreting, and Presenting Nonlinear Interaction Effects. Sociological Science 6: 81-117. [CrossRef]

Mood, Carina. 2010. Logistic Regression: Why We Cannot Do What We Think We Can Do, and What We Can Do About It. European Sociological Review 26: 67-82. [CrossRef]

Müller, Walter, and Reinhard Pollak. 2015. Bildung und soziale Mobilität in Deutschland. AStA Wirtschafts- und Sozialstatistisches Archiv 9: 5-26. [CrossRef]

Müller, Walter, and Yossi Shavit. 1998. The institutional embeddedness of the stratification process: a comparative study of qualifications and occupations in thirteen countries. In From School to Work. A Comparative Study of Educational Qualifications and Occupational Destinations. Edited by Walter Müller and Yossi Shavit. Oxford: Clarendon Press, pp. 1-48.

Nieto, Sandra, Alessia Matano, and Raúl Ramos. 2015. Educational mismatches in the EU: immigrants vs. natives. International Journal of Manpower 36: 540-61. [CrossRef]

Ortiz, Luis, and Aleksander Kucel. 2008. Do fields of study matter for over-education? The cases of Spain and Germany. International Journal of Comparative Sociology 49: 305-27. [CrossRef]

Ortiz, Luis, and Jorge Rodriguez-Menés. 2016. The Positional Value of Education and its Effect on General and Technical Fields of Education: Educational Expansion and Occupational Returns to Education in Spain. European Sociological Review 32: $216-37$. [CrossRef]

Paulus, Wiebke, and Britta Matthes. 2013. Klassifikation der Berufe: Struktur, Codierung und Umsteigeschlüssel. Nuremberg: für Arbeitsmarkt-und Berufsforschung (IAB), Nuremberg: Institute for Employment Research.

Pollmann-Schult, Matthias, and Felix Büchel. 2004. Career Prospects of Overeducated Workers in West Germany. European Sociological Review 20: 321-31. [CrossRef]

Quintini, Glenda. 2011. Right for the Job: Over-qualified or Under-qualified. In OECD Social, Employment and Migration Workingpapers. No. 120. Paris: OECD Publishing. [CrossRef] 
Reichelt, Malte, and Basha Vicari. 2014. Ausbildungsinadäquate Beschäftigung in Deutschland: Im Osten sind vor allem Ältere für ihre Tätigkeit formal überqualifiziert. In IAB-Kurzbericht 25/2014. Nürnberg: Institut für Arbeitsmarkt- und Berufsforschung der Bundesagentur für Arbeit.

Reimer, David, and Reinhard Pollak. 2010. Educational Expansion and Its Consequences for Vertical and Horizontal Inequalities in Access to Higher Education in West Germany. European Sociological Review 26: 415-30. [CrossRef]

Reimer, David, Clemens Noelke, and Aleksander Kucel. 2008. Labor Market Effects of Field of Study in Comparative Perspective: An Analysis of 22 European Countries. International Journal of Comparative Sociology 49: 233-56. [CrossRef]

Rohrbach-Schmidt, Daniela, and Anja Hall. 2020. BIBB/BAuA Employment Survey 2018, 1st ed. BIBB-FDZ Data and Methodological Report 1/2020. Bonn: BIBB.

Rohrbach-Schmidt, Daniela, and Michael Tiemann. 2011. Mismatching and job tasks in Germany-rising over-qualification through polarization? Empirical Research in Vocational Education and Training 3: 39-53. [CrossRef]

Rohrbach-Schmidt, Daniela, and Michael Tiemann. 2016. Educational (Mis) match and skill utilization in Germany: Assessing the role of worker and job characteristics. Journal for Labour Market Research 49: 99-119. [CrossRef]

Rossen, Anja, Christina Boll, and André Wolf. 2019. Patterns of Overeducation in Europe: The Role of Field of Study. IZA Journal of Labor Policy 9. [CrossRef]

Salas-Velasco, Manuel. 2021. Mapping the (mis)match of university degrees in the graduate labor market. Journal for Labour Market Research 55: 14. [CrossRef]

Schindler, Steffen, and David Reimer. 2011. Differentiation and social selectivity in German higher education. Higher Education 61: 261-75. [CrossRef]

Schuss, Eric. 2020. Do Ethnic Networks Ameliorate Education-Occupation Mismatch? LABOUR 34: 441-76. [CrossRef]

Shavit, Yossi, and Hans-Peter Blossfeld. 2003. Persistent Inequality: Changing Educational Attainment in Thirteen Countries. Boulder: Westview Press.

Sichermann, Nachum. 1991. 'Overeducation' in the labour market. Journal of Labor Economics 9: 101-22. [CrossRef]

Sichermann, Nachum, and Oded Galor. 1990. A theory of career mobility. Journal of Political Economy 98: 169-92. [CrossRef]

Sloane, Peter J., Harminder Battu, and Paul T. Seaman. 1999. Overeducation, undereducation and the British labour market. Applied Economics 31: 1437-53. [CrossRef]

Solga, Heike, and Dirk Konietzka. 2000. Das Berufsprinzip des deutschen Arbeitsmarktes: Ein geschlechtsneutraler Allokationsmechanismus? Schweizerische Zeitschrift für Soziologie 26: 111-47.

Spence, Michael. 1973. Job market signaling. The Quarterly Journal of Economics 87: 355-74. [CrossRef]

Spitz-Oener, Alexandra. 2006. Technical change, job tasks, and rising educational demands: Looking outside the wage structure. Journal of Labor Economics 24: 235-70. [CrossRef]

Statistisches Bundesamt. 2020. Bildungsstand der Bevölkerung_Ergebnisse des Mikrozensus 2019. Wiesbaden: Statistisches Bundesamt (Destatis).

Thurow, Lester C. 1975. Generating Inequality. New York: Basic Books.

Torche, Florencia. 2011. Is a College Degree Still the Great Equalizer? Intergenerational Mobility across Levels of Schooling in the United States. American Journal of Sociology 117: 763-807. [CrossRef]

Triventi, Moris. 2013. Stratification in Higher Education and Its Relationship with Social Inequality: A Comparative Study of 11 European Countries. European Sociological Review 29: 489-502. [CrossRef]

Triventi, Moris, Nazareno Panichella, Gabriele Ballarino, Carlo Barone, and Fabrizio Bernardi. 2016. Education as a positional good: Implications for social inequalities in educational attainment in Italy. Research in Social Stratification and Mobility 43: 39-52. [CrossRef]

Triventi, Moris, Loris Vergolini, and Nadir Zanini. 2017. Do individuals with high social background graduate from more rewarding fields of study? Changing patterns before and after the 'Bologna process'. Research in Social Stratification and Mobility 51: 28-40. [CrossRef]

Verhaest, Dieter, and Eddy Omey. 2010. The determinants of overeducation: Different measures, different outcomes? International Journal of Manpower 31: 608-25. [CrossRef]

Verhaest, Dieter, and Rolf Van der Velden. 2013. Cross-country differences in graduate overeducation. European Sociological Review 29: 642-53. [CrossRef]

Verhaest, Dieter, Sana Sellami, and Rolf van der Velden. 2017. Differences in horizontal and vertical mismatches across countries and fields of study. International Labour Review 156: 1-23. [CrossRef]

Weeden, Kim A. 2002. Why do some occupations pay more than others? Social closure and earnings inequality in the United States. American Journal of Sociology 108: 55-101. [CrossRef]

Weiss, Felix, and Markus Klein. 2011. Soziale Netzwerke und Jobfindung von Hochschulabsolventen—Die Bedeutung des Netzwerktyps für monetäre Arbeitsmarkterträge und Ausbildungsadäquatheit. Zeitschrift für Soziologie 40: 228-45. [CrossRef]

Witteveen, Dirk, and Paul Attewell. 2020. Reconsidering the 'meritocratic power of a college degree'. Research in Social Stratification and Mobility 66: 100479. [CrossRef] [PubMed] 